\title{
Aerobic and anaerobic ammonium-oxidising bacterial enrichment from municipal solid waste
}

\author{
S. Sri Shalini $\cdot$ J. Kurian $\cdot$ J. W. C. Wong
}

Received: 12 October 2012/Revised: 3 September 2013/ Accepted: 14 December 2013/Published online: 9 January 2014

(C) Islamic Azad University (IAU) 2014

\begin{abstract}
Leachate from the municipal solid waste (MSW) landfills contains high concentration of ammoniacal nitrogen that is a major toxic pollutant that has a great threat to environment. Among the processes available for the removal of ammoniacal nitrogen, one process is a combination of partial nitrification and anaerobic ammonium oxidation (anammox) process. It requires aerobic ammonium-oxidising bacteria (AOB) and anaerobic ammonium-oxidising bacteria (AnAOB). This paper presents the feasibility of enriching the AOB and AnAOB in $100-\mathrm{mL}$ and $2.5-\mathrm{L}$ batch reactors from fresh and mined MSW and leachate under aerobic and anaerobic conditions with varying feed-to-seed ratio. The $\mathrm{AOB}$ and AnAOB activity was monitored by measuring the intermediates such as hydroxylamine and hydrazine along with variations in ammoniacal nitrogen, nitrite nitrogen, and nitrate nitrogen concentrations in the reactor contents. The formation of intermediates such as hydroxylamine and hydrazine and ammoniacal nitrogen transformation data confirmed the enrichment of AOB and AnAOB. Further, $\mathrm{AOB}$ and $\mathrm{AnAOB}$ were validated by most probable number test and scanning electron microscopy analysis,
\end{abstract}

Electronic supplementary material The online version of this article (doi:10.1007/s13762-013-0486-7) contains supplementary material, which is available to authorized users.

S. Sri Shalini $(\bowtie) \cdot$ J. Kurian

Centre for Environmental Studies, Anna University, Chennai,

India

e-mail: srishalini10@gmail.com

J. W. C. Wong

Department of Biology, Hong Kong Baptist University,

Kowloon Tong, Hong Kong, SAR respectively. DNA extraction, polymerase chain reaction amplification, and sequencing analysis authenticated the AnAOB as Candidatus Brocadia anammoxidans.

Keywords Bacterial enrichment - Ammoniacal nitrogen removal - Aerobic ammonium-oxidising bacteria . Anammox bacteria $\cdot$ Feed-to-seed ratio $\cdot$ Candidatus Brocadia anammoxidans

\section{Introduction}

Leachate from landfills contains high concentration of ammoniacal nitrogen (around 500-3,000 $\mathrm{mg} / \mathrm{L}$ ) that has to be removed due to its aquatic toxicity, high oxygen demand in receiving waters, impact on post-closure monitoring, inhibits anaerobic degradation of waste, affects human health, and to meet the environmental discharge standard limits (Berge et al. 2005). Physical/chemical methods for ammoniacal nitrogen removal have several disadvantages like high chemical costs and high-energy consumption, and cause secondary pollution. Biological methods are more economical and effective because of lower running costs and more convenient operation when compared with the physical/chemical methods (Liang and Liu 2007).

Several biological processes are available for the removal of ammoniacal nitrogen from leachate. Among them, the conventional processes are nitrification and denitrification. Nitrification process involves the oxidation of ammoniacal nitrogen to nitrite by aerobic ammoniumoxidising bacteria (AOB), followed by the oxidation of nitrite by nitrite-oxidising bacteria (NOB). The denitrification step reduces the nitrate or nitrite to nitrogen gas by denitrifying bacteria (Van de Graaf et al. 1996). The 
conventional biological treatment processes are expensive due to the requirement of high amount of oxygen supply for nitrification and elevated dosage of external carbon supplementation for denitrification (Ganigue et al. 2009). It will also results in the emission of nitrous oxides $\left(\mathrm{N}_{2} \mathrm{O}\right)$. Innovative process for overcoming the problems in conventional process includes completely autotrophic nitrogen removal over nitrite (CANON), oxygen-limited autotrophic nitrification and denitrification (OLAND), and combination of single reactor system for high activity ammonia removal over nitrite-anaerobic ammonium oxidation (SHARONANAMMOX). Among the innovative processes, the SHARON-ANAMMOX process has several advantages over others like lower oxygen and alkalinity consumption; non-requirement of organic carbon addition; non-production of by-products like $\mathrm{N}_{2} \mathrm{O}$, lower nitrite, and nitrate production; negligible sludge production; lower investment; and operational cost required (Ahn 2006; Jetten et al. 2002).

SHARON process is a partial nitrification process, which oxidises half the influent ammonia to nitrite according to the Eq. 1 (Ganigue et al. 2009) through hydroxylamine $\left(\mathrm{NH}_{2} \mathrm{OH}\right)$ as intermediate is carried out by AOB (Peng and Zhu 2006) such as Nitrosomonas europaea, Nitrosomonas eutropha, Nitrosolobus sp., Nitrosopira sp., and Nitrosovibrio sp. (Ahn 2006; Van de Graaf et al. 1996) developed in the 1990s at the Delft University of Technology.

$$
\begin{aligned}
\mathrm{NH}_{4}+0.75 \mathrm{O}_{2}+\mathrm{HCO}_{3}^{-} \rightarrow & 0.5 \mathrm{NO}_{2}^{-}+0.5 \mathrm{NH}_{4}^{+}+\mathrm{CO}_{2} \\
& +1.5 \mathrm{H}_{2} \mathrm{O}
\end{aligned}
$$

In ANAMMOX process, ammonia is oxidised anaerobically using the nitrite produced in the SHARON process as electron acceptor as in Eq. 2 by anaerobic ammonium-oxidising bacteria (AnAOB) like Candidatus Brocadia anammoxidans and Candidatus Kuenenia stuttgartiensis (Dapena-Mora et al. 2004).

$$
\begin{aligned}
\mathrm{NH}_{4}^{+} & +1.32 \mathrm{NO}_{2}^{-}+0.066 \mathrm{HCO}_{3}^{-}+0.13 \mathrm{H}^{+} \\
\rightarrow & 1.02 \mathrm{~N}_{2}+0.26 \mathrm{NO}_{3}^{-}+0.066 \mathrm{CH}_{2} \mathrm{O}_{0.5} \mathrm{~N}_{0.15} \\
& +2.03 \mathrm{H}_{2} \mathrm{O}
\end{aligned}
$$

The SHARON and ANAMMOX process has been widely applied for ammonium-rich wastewaters like sludge liquor, sludge digestate, sludge supernatant, and synthetic wastewaters (Fux et al. 2002; Zhang et al. 2008; Ganigue et al. 2009). The treatment of high ammonium concentrations more than $5,000 \mathrm{mg} / \mathrm{L}$ from municipal solid waste (MSW) using SHARON and ANAMMOX process has not been addressed previously. SHARON-ANAMMOX process is limited by the low availability of $\mathrm{AOB}$ and AnAOB biomass. The biomass yield, doubling time, and specific growth rate of $\mathrm{AOB}$ and $\mathrm{AnAOB}$ have been reported to be $0.08 \mathrm{~mol} / \mathrm{mol} \mathrm{C}, 0.73 \mathrm{~d}$ and $0.04 \mathrm{~h}^{-1}$, $0.066 \pm 0.01 \mathrm{C}-\mathrm{mol} / \mathrm{mol}$ ammonium, $11 \mathrm{~d}$ and $0.0027 \mathrm{~h}^{-1}$, respectively (Strous et al. 1998; Guven et al. 2004; Ahn 2006). Usage of nitrification sludge, denitrification sludge, anaerobic digestion sludge, and upflow anaerobic sludge blanket as seed for AnAOB (Chamchoi and Nitisoravut 2007; Zhang et al. 2008) in different reactors configurations like rotating biological contactor (RBC), trickling filter, packed bed, fluidized bed, sequencing batch reactor (SBR) under limited oxygen and anoxic conditions (van Dongen et al. 2001), air/gas lift reactors, wetlandbased systems (Paredes et al. 2007), upflow anaerobic sludge blanket (UASB), upflow stationary fixed film (USFF), anaerobic sequencing batch reactor (ASBR) (Jin et al. 2008), and completely stirred tank reactor (CSTR) (Guven et al. 2004) was studied. Activated sludge as seed for AOB is common, and it was conducted in different reactor configurations like CSTR, SBR, biofilm reactor, and swim-bed reactors (Fux and Siegrist 2004; Ganigue et al. 2009; Van Dongen et al. 2001) were carried out. But, usage of MSW as seed for enriching the AOB and AnAOB bacteria was not studied so far and it is an innovative research. The AOB and AnAOB bacterial enrichment from MSW will remove the toxic ammoniacal nitrogen and protects the environment through sustainable nitrogen management.

The main purpose of this present study is to assess the feasibility for enriching the AOB and AnAOB from different seeds like fresh MSW, mined MSW, slurry, and landfill leachate in 100-mL batch reactors. Based on the outcomes obtained in batch reactors, the mined MSW for the enrichment of AOB and AnAOB in 2.5-L reactors was studied in detail. The research described in this paper was performed in the laboratories of Centre for Environmental Studies, Anna University, Chennai, in 2011-2012 and the molecular work (DNA extraction, PCR amplification, cloning, and sequencing of 16S rRNA) was carried out in the laboratories of Hong Kong Baptist University, Hong Kong, in 2011.

\section{Materials and methods}

Seed collection

Biodegradable fraction of fresh MSW, mined MSW (i.e. partially degraded MSW-3 years old), leachate (effluent generated as a consequence of rainwater percolation through MSW and inherent water content of MSW), and 
Fig. 1 The schematic diagram of the experimental set-up for the enrichment of $\mathrm{AOB}$ (a and b) and anammox (c and d). Description The design and operation of the $100-\mathrm{mL}$ and 2.5-L reactors for the enrichment of $\mathrm{AOB}$ and AnAOB is depicted (a)

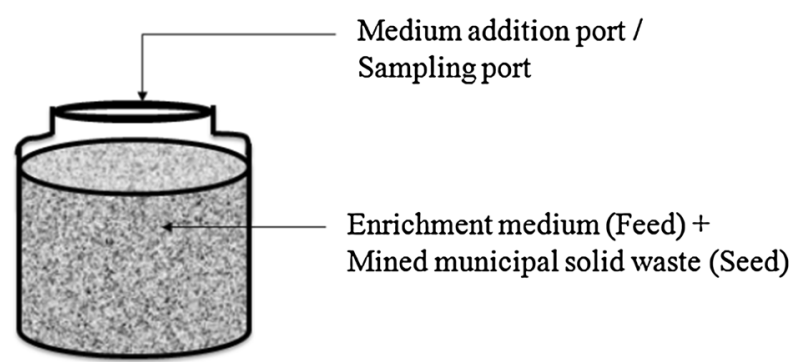

(b)

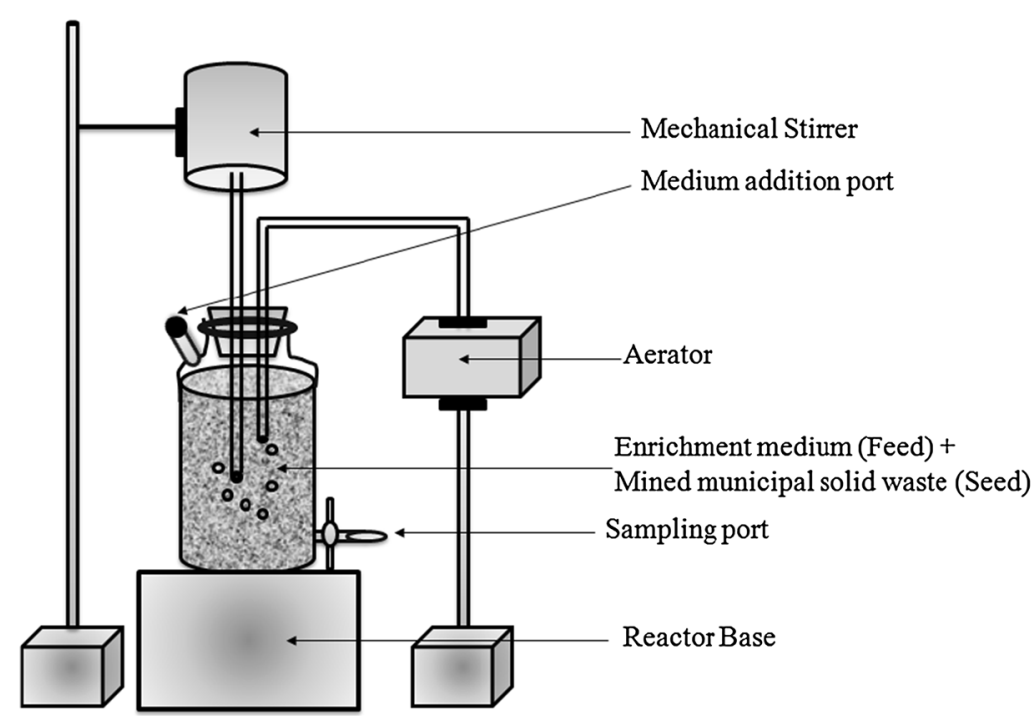

(c)

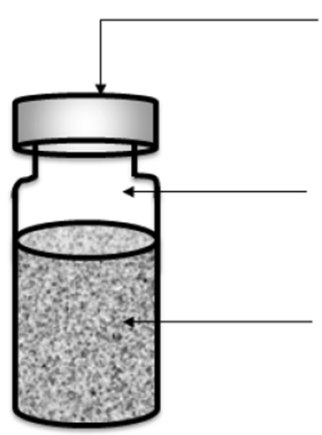

Medium addition port / Sampling port

Head space

( $40 \%$ of reactor volume)

Enrichment medium(Feed) + Mined municipal solid waste (Seed) (60\% of reactor volume)

(d)

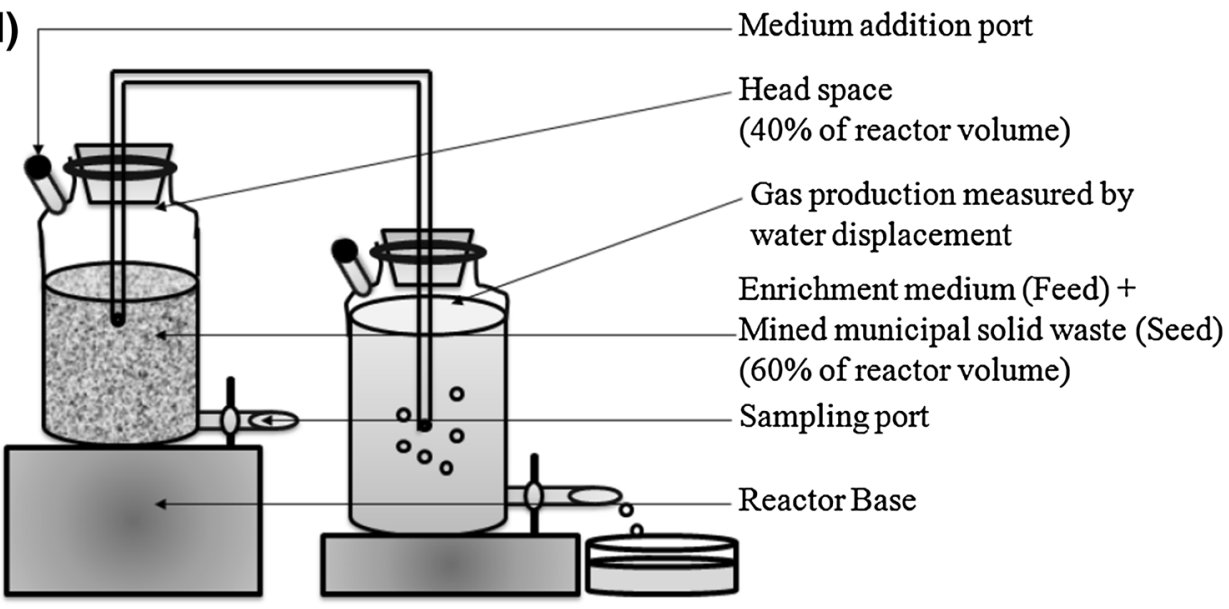


slurry (mixture of MSW and leachate) was collected from a MSW dumping ground in Chennai, India, and was used as seed for 100-mL reactors. Second sampling of mined waste was carried out in the same dumping ground, which was used as seed for $2.5-\mathrm{L}$ reactors in this study.

Experimental set-up for the enrichment of AOB in aerobic reactors

Enrichment of aerobic ammonium-oxidising bacteria from MSW was carried out in $100-\mathrm{mL}$ and $2.5-\mathrm{L}$ batch reactors as shown in Fig. 1a, b for 30 and 65 days, respectively, and enriched $\mathrm{AOB}$ in the reactors was quantified by most probable number (MPN) technique. The AOB enrichment medium was used as feed in the study and its composition is presented in Table 1, which was specifically described by Egli et al. (2003). Nine reactors were operated with varying feed-to-seed ratio (70/30 and 80/20) namely fresh MSW 70/30 (FA), fresh MSW 80/20 (FB), mined MSW 70/30 (MA), mined MSW 80/20 (MB), slurry 70/30 (SA), slurry 80/20 (SB), leachate 70/30 (LA), and leachate 80/20 (LB), respectively, in $100-\mathrm{mL}$ reactors and mined MSW 80/20 $\left(\mathrm{M}_{\mathrm{AOB}}\right)$ in $2.5-\mathrm{L}$ reactor. The loading details of the reactors are presented in the Table 2 (a). All the reactors were run in duplicates and its replicability was validated by Pearson's correlation analysis. The $100-\mathrm{mL}$ reactors were made up of plastic, and 2.5 -L reactors were made of borosilicate glass. The dissolved oxygen level was maintained above $1 \mathrm{mg} / \mathrm{L}$ in the batch reactors (Paredes et al. 2007).

Experimental set-up for the enrichment of AnAOB in anaerobic reactors

Enrichment of anammox bacteria from MSW was carried out in $100-\mathrm{mL}$ and $2.5-\mathrm{L}$ batch reactors as shown in Fig. 1c, d for 30 and 65 days, respectively. The AnAOB enrichment medium was used as feed in the study and its composition is presented in Table 1, which was specifically described by Van de Graaf et al. (1996). Five reactors were operated with feed-to-seed ratio of 60/40 namely fresh MSW (FC), mined MSW (MC), slurry (SC), and leachate (LC), respectively, in 100-mL reactors and mined MSW $\left(\mathrm{M}_{\mathrm{AnAOB}}\right)$ in 2.5-L reactor, and its loading details are given in the Table 2 (b). The reactors were made up of borosilicate glass and were run in duplicates validated by correlation analysis. The $100-\mathrm{mL}$ reactors were covered with aluminium foil, and $2.5 \mathrm{~L}$ reactor was covered with black cloth to avoid light interference. Anoxic condition was maintained by suffocation (i.e. cutting the supply of oxygen) method, and gas generation was monitored by water displacement method.
Table 1 Composition of the enrichment medium

\begin{tabular}{|c|c|c|c|}
\hline $\begin{array}{l}\text { S. } \\
\text { No }\end{array}$ & $\begin{array}{l}\text { Medium chemical } \\
\text { composition } \\
\text { Chemical }\end{array}$ & $\begin{array}{l}\text { AOB } \\
\text { Enrichment } \\
\text { medium } \\
\text { Concentration }\end{array}$ & $\begin{array}{l}\text { Anaerobic } \\
\text { enrichment medium }\end{array}$ \\
\hline 1. & $\mathrm{KH}_{2} \mathrm{PO}_{4}$ & $4.185 \mathrm{~g}$ & $0.025 \mathrm{~g}$ \\
\hline 2. & $\mathrm{CaCl}_{2}$ & $0.074 \mathrm{~g}$ & $0.3 \mathrm{~g}$ \\
\hline 3. & $\mathrm{MgCl}_{2}$ & $0.102 \mathrm{~g}$ & $0.165 \mathrm{~g}$ \\
\hline 4. & EDTA & $0.372 \mathrm{~g}$ & $0.007 \mathrm{~g}$ \\
\hline 5. & $\mathrm{FeSO}_{4}$ & - & 0.012 \\
\hline 6. & $\mathrm{NaHCO}_{3}$ & & $1.05 \mathrm{~g}$ \\
\hline 7. & $\mathrm{~K}_{2} \mathrm{HPO}_{4}$ & $3.352 \mathrm{~g}$ & - \\
\hline 8. & $\mathrm{KHCO}_{3}$ & $1.001 \mathrm{~g}$ & - \\
\hline 9. & $\mathrm{Na}_{2} \mathrm{SO}_{4}$ & $0.426 \mathrm{~g}$ & - \\
\hline \multirow[t]{3}{*}{10.} & $\begin{array}{l}\text { Trace element solution } \\
\text { I }\end{array}$ & $(2.0 \mathrm{~mL})$ & - \\
\hline & $\mathrm{Na}_{2}$ EDTA· $2 \mathrm{H}_{2} \mathrm{O}$ & $10 \mathrm{~g} / \mathrm{L}$ & \\
\hline & $\mathrm{FeSO}_{4}$ & $5 \mathrm{~g} / \mathrm{L}$ & \\
\hline \multirow[t]{10}{*}{11.} & $\begin{array}{l}\text { Trace element solution } \\
\text { II }\end{array}$ & $(1.0 \mathrm{~mL})$ & $(1.25 \mathrm{~mL})$ \\
\hline & EDTA & $15 \mathrm{~g} / \mathrm{L}$ & $15 \mathrm{~g} / \mathrm{L}$ \\
\hline & $\mathrm{ZnSO}_{4} \cdot 7 \mathrm{H}_{2} \mathrm{O}$ & $0.43 \mathrm{~g} / \mathrm{L}$ & $0.43 \mathrm{~g} / \mathrm{L}$ \\
\hline & $\mathrm{CoCl}_{2} \cdot 6 \mathrm{H}_{2} \mathrm{O}$ & $0.24 \mathrm{~g} / \mathrm{L}$ & $0.24 \mathrm{~g} / \mathrm{L}$ \\
\hline & $\mathrm{MnCl}_{2} \cdot 4 \mathrm{H}_{2} \mathrm{O}$ & $0.99 \mathrm{~g} / \mathrm{L}$ & $0.99 \mathrm{~g} / \mathrm{L}$ \\
\hline & $\mathrm{CuSO}_{4} \cdot 5 \mathrm{H}_{2} \mathrm{O}$ & $0.25 \mathrm{~g} / \mathrm{L}$ & $0.25 \mathrm{~g} / \mathrm{L}$ \\
\hline & $\mathrm{Na}_{2} \mathrm{MoO}_{4} \cdot 2 \mathrm{H}_{2} \mathrm{O}$ & $0.22 \mathrm{~g} / \mathrm{L}$ & $0.22 \mathrm{~g} / \mathrm{L}$ \\
\hline & $\mathrm{NiCl}$ & $0.19 \mathrm{~g} / \mathrm{L}$ & $0.19 \mathrm{~g} / \mathrm{L}$ \\
\hline & $\mathrm{Na}_{2} \mathrm{SeO}_{4} \cdot 10 \mathrm{H}_{2} \mathrm{O}_{2} \cdot 6 \mathrm{H}_{2} \mathrm{O}$ & $0.32 \mathrm{~g} / \mathrm{L}$ & $0.32 \mathrm{~g} / \mathrm{L}$ \\
\hline & $\mathrm{H}_{3} \mathrm{BO}_{3}$ & $0.014 \mathrm{~g} / \mathrm{L}$ & $0.014 \mathrm{~g} / \mathrm{L}$ \\
\hline
\end{tabular}

Reactor operation, monitoring, and analytical techniques

The reactors were operated in fed-batch mode [i.e. intermittent supply of enrichment medium for maintaining the working volume in the reactor occurred due to sampling and evaporation (especially, in aerobic reactors)]. The experiment was carried out at ambient temperature. The $\mathrm{pH}$ of the reactors was not maintained during the course of the study. Complete mixing was achieved within the reactors by manual methods and using mechanical stirrers. About $2.5 \mathrm{~mL}$ of sample was collected from 100-mL reactors once in a day and $25 \mathrm{~mL}$ of sample was collected from 2.5$\mathrm{L}$ reactors once in 3 days from the sampling port. The quantity of samples withdrawn was replaced with the addition of enrichment medium [2.5 mL (100-mL reactors) and $25 \mathrm{~mL}$ (2.5-L reactors)] in the medium addition port without any nitrogen supplement.

The samples were analysed for the enrichment of AOB and AnAOB bacterial population in terms of nitrogen transformations of ammoniacal nitrogen, nitrite and nitrate 
Table 2 The reactor loading details for the enrichment of AOB and AnAOB

\begin{tabular}{|c|c|c|c|c|c|c|}
\hline $\begin{array}{l}\text { Sl. } \\
\text { no }\end{array}$ & $\begin{array}{l}\text { Reactor } \\
\text { labels }\end{array}$ & Seed & $\begin{array}{l}\text { Reactor volume and sampling } \\
\text { frequency }\end{array}$ & $\begin{array}{l}\text { Feed/seed } \\
\text { ratio }\end{array}$ & $\begin{array}{l}\text { Feed volume } \\
(\mathrm{mL})\end{array}$ & $\begin{array}{l}\text { Seed concentration ( } \mathrm{g} \text { of } \\
\text { TS) }\end{array}$ \\
\hline \multicolumn{7}{|c|}{ (a) Enrichment of $A O B$} \\
\hline 1. & FA & Fresh MSW & $100 \mathrm{~mL}$ & $70 / 30$ & 70 & 15.46 \\
\hline 2. & FB & Fresh MSW & Once in a day & $80 / 20$ & 80 & 13.35 \\
\hline 3. & MA & $\begin{array}{l}\text { Mined } \\
\text { MSW }\end{array}$ & (100 mL as working volume) & $70 / 30$ & 70 & 24.78 \\
\hline 4. & MB & $\begin{array}{l}\text { Mined } \\
\text { MSW }\end{array}$ & & $80 / 20$ & 80 & 20.86 \\
\hline 5. & SA & Slurry & & $70 / 30$ & 70 & 29.27 \\
\hline 6. & SB & Slurry & & $80 / 20$ & 80 & 36.35 \\
\hline 7. & LA & Leachate & & $70 / 30$ & 70 & $30 \mathrm{~mL}$ \\
\hline 8. & LB & Leachate & & $80 / 20$ & 80 & $20 \mathrm{~mL}$ \\
\hline 9. & $\mathrm{M}_{\mathrm{AOB}}$ & $\begin{array}{l}\text { Mined } \\
\text { MSW }\end{array}$ & $\begin{array}{l}2.5 \mathrm{~L} \\
\text { Once in three days } \\
(1.8 \mathrm{~L} \text { as working volume })\end{array}$ & $80 / 20$ & 1,440 & 337 \\
\hline \multicolumn{7}{|c|}{ (b) Enrichment of $A n A O B$} \\
\hline 1. & $\mathrm{FC}$ & Fresh MSW & $100 \mathrm{~mL}$ & $60 / 40$ & 36 & 11.89 \\
\hline 2. & $\mathrm{MC}$ & $\begin{array}{l}\text { Mined } \\
\text { MSW }\end{array}$ & $\begin{array}{l}\text { Once in a day } \\
\text { ( } 60 \% \text { as working volume) }\end{array}$ & $60 / 40$ & 36 & 13.89 \\
\hline 3. & $\mathrm{SC}$ & Slurry & & $60 / 40$ & 36 & 25.71 \\
\hline 4. & $\mathrm{LC}$ & Leachate & & $60 / 40$ & 36 & $40 \mathrm{~mL}$ \\
\hline 5. & $\mathrm{M}_{\mathrm{AnAOB}}$ & $\begin{array}{l}\text { Mined } \\
\text { MSW }\end{array}$ & $\begin{array}{l}2.5 \mathrm{~L} \\
\text { Once in three days } \\
\text { (60\% as working volume) }\end{array}$ & $60 / 40$ & 864 & 473 \\
\hline
\end{tabular}

nitrogen, trace appearance of intermediates such as hydrazine and hydroxylamine and bacterial biomass accumulation by MLVSS and MLSS analyses. The various analytical techniques used for the characterisation of solid waste samples and reactor samples in the study are summarised in Table 3. Confirmation of the AOB population in reactors was analysed by MPN tests, and AnAOB/anammox bacterial population in reactors was examined by SEM and sequencing analysis of $16 \mathrm{~S}$ rRNA.

\section{Calculations}

The nitrite accumulation rate in aerobic reactors was calculated by partial nitritation efficiency (PNE) according to Liang and Liu (2007) as given in the Eq. 3.

$\mathrm{PNE}=\frac{C_{\left(\mathrm{NO}_{2}-\mathrm{N}\right)_{\mathrm{eff}}}}{C_{\left(\mathrm{NO}_{2}-\mathrm{N}\right)_{\text {eff }}}+C_{\left(\mathrm{NO}_{3}-\mathrm{N}\right)_{\mathrm{eff}}}} \times 100 \%$

where $C_{\left(\mathrm{NO}_{2}-\mathrm{N}\right)_{\text {eff }}}$ - concentrations of nitrite nitrogen in the effluent $(\mathrm{mg} / \mathrm{L}), C_{\left(\mathrm{NO}_{3}-\mathrm{N}\right)_{\mathrm{eff}}}$ - concentrations of nitrate nitrogen in the effluent $(\mathrm{mg} / \mathrm{L})$, Concentrations of free ammonia (FA) and free nitrous acid (FNA) in the reactors were calculated according to the Eqs. 4 and 5 suggested by Anthonisen et al. (1976).

$\mathrm{FA}\left(\mathrm{NH}_{3}, \mathrm{mg} / \mathrm{L}\right)=\frac{17}{14} \frac{\left(\mathrm{NH}_{4}\right) \times 10^{\mathrm{pH}}}{e^{(6344 /(273+\mathrm{t}))}+10^{\mathrm{pH}}}$

$\mathrm{FNA}\left(\mathrm{HNO}_{2}, \mathrm{mg} / \mathrm{L}\right)=\frac{46}{14} \frac{\left(\mathrm{NO}_{2}\right)}{e^{(-2300 /(273+\mathrm{t}))} \times 10^{\mathrm{pH}}}$

where $17 / 14$ is the molecular weight of the ammonia/ atomic weight of the nitrogen, $46 / 14$ is the molecular weight of the nitrous acid/atomic weight of the nitrogen.

Scanning electron microscopy (SEM) image analysis

The physical nature and the surface morphology of the anaerobic reactor samples were determined during the end of the study period using scanning electron microscopy (Arrojo et al. 2006; Ni et al. 2010). The AnAOB biomass from each reactor samples (FC, MC, SC, and LC) was taken for SEM analysis. The samples were dried using hot air sparger, dehydrated with ethanol, gold coated by Cressington sputter coater, Model 108 auto for $30 \mathrm{~s}$ and observed in the scanning electron microscope, model no. Quanta 200 F manufactured by FEI, Germany. 
Table 3 Analytical procedure for the characterisation of solid waste and reactor samples

\begin{tabular}{|c|c|c|c|c|}
\hline $\begin{array}{l}\text { Sl. } \\
\text { no. }\end{array}$ & Parameter & Method & Instrument & $\begin{array}{l}\text { Reference } \\
\text { (APHA 1998) }\end{array}$ \\
\hline \multicolumn{5}{|c|}{ Analysis for mined $M S W$} \\
\hline 1. & Moisture & Gravimetric method & Oven, balance & $2540-B$ \\
\hline 2. & Volatile solids & $\begin{array}{l}\text { Loss on ignition at } \\
550{ }^{\circ} \mathrm{C}\end{array}$ & Muffle furnace, balance & $2540-\mathrm{E}$ \\
\hline 3. & Carbon & Walkley-Black method & - & Behera 2006 \\
\hline 4. & Ammonia-N & Distillation & Distillation unit & $4500 \mathrm{NH}_{3} \mathrm{C}$ \\
\hline 5. & Nitrate-N & Colorimetric method & Spectrophotometer & $4500 \mathrm{NO}_{3}^{-} \mathrm{C}$ \\
\hline 6. & Nitrite-N & Colorimetric method & Spectrophotometer & $4500 \mathrm{NO}_{2}^{-} \mathrm{C}$ \\
\hline 7. & $\begin{array}{l}\mathrm{pH} \text { (slurry } \\
\text { preparation) }\end{array}$ & Potentiometry & pH 197, WTW Germany meter & $4500 \mathrm{~B}$ \\
\hline \multicolumn{5}{|c|}{ Analysis for reactor samples } \\
\hline 1. & $\mathrm{pH}$ & Potentiometry & pH 197, WTW Germany & $4500 \mathrm{~B}$ \\
\hline 2. & Temperature & Thermometry & $\begin{array}{l}\text { Ecoscan } \mathrm{pH} / \mathrm{mV} /{ }^{\circ} \mathrm{C} \text { meter (Eutech instruments, } \\
\text { Singapore) }\end{array}$ & - \\
\hline 3. & Conductivity & Conductometry & LF 197, WTW Germany & $2510 \mathrm{~B}$ \\
\hline 4. & Dissolved oxygen & DO probe & Oxi 197, WTW Germany & - \\
\hline 5. & COD & Dichromate digestion & COD digester & $5220 \mathrm{C}$ \\
\hline 6. & MLSS & Gravimetric method & Oven, balance & $2540 \mathrm{~B}$ \\
\hline 7. & MLVSS & $\begin{array}{l}\text { Loss on ignition at } \\
550{ }^{\circ} \mathrm{C}\end{array}$ & Muffle furnace, balance & $2540-\mathrm{E}$ \\
\hline 8. & Ammonia-N & Distillation & Distillation unit & $4500 \mathrm{NH}_{3} \mathrm{C}$ \\
\hline 9. & Nitrate-N & Colorimetric method & Spectrophotometer & $4500 \mathrm{NO}_{3}^{-} \mathrm{C}$ \\
\hline 10. & Nitrite-N & Colorimetric method & Spectrophotometer & $4500 \mathrm{NO}_{2}^{-} \mathrm{C}$ \\
\hline 11. & Hydrazine & Colorimetric method & Spectrophotometer & Watt and Chrisp (1952) \\
\hline 12. & Hydroxylamine & Colorimetric method & Spectrophotometer & $\begin{array}{l}\text { Frear and Burrell } \\
\quad(1955)\end{array}$ \\
\hline
\end{tabular}

DNA extraction, PCR amplification, cloning, and sequencing of $16 \mathrm{~S}$ rRNA

The identification of the anammox bacteria in $\mathrm{M}_{\mathrm{AnAOB}}$ reactor was carried out by molecular techniques. DNA was extracted from biomass samples of $\mathrm{M}_{\mathrm{AnAOB}}$ reactor using QIAmp DNA mini kit (Qiagen). DNA quality was assessed by $2 \%$ agarose gel electrophoresis, and concentrations were measured with the NanoDrop ND-1000. For the detection of anammox bacteria, a specific polymerase chain reaction (PCR) amplification of anammox 16S rRNA gene was performed with primers Brod541F (GAG CACGTAGGTGGGTTTGT) (Penton et al. 2006) and Amx820R (AAAACCCCTCTACTTAGTGCCC) (Amano et al. 2007). The PCR conditions used to target anammox bacteria consisted of initial denaturation at $94{ }^{\circ} \mathrm{C}$ for $5 \mathrm{~min}$, followed by 41 cycles of denaturation at $94{ }^{\circ} \mathrm{C}$ for $45 \mathrm{~s}$, annealing at $55^{\circ} \mathrm{C}$ for $1 \mathrm{~min}$ and extension at $72{ }^{\circ} \mathrm{C}$ for $1 \mathrm{~min}$, with a final extension step of $72{ }^{\circ} \mathrm{C}$ for $10 \mathrm{~min}$. The PCR products were electrophoresed on a $2 \%$ agarose gel. The DNA was eluted from the gel and purified by using Wizard SV gel and PCR clean-up system (Promega, USA). PCR fragments were cloned using the pGEM-T Easy cloning kit (Promega, USA) according to the manufacturer's instructions. Plasmid DNA was isolated and purified with the Pure Yield ${ }^{\mathrm{TM}}$ Plasmid Miniprep kit (Promega, USA). Plasmid purity was measured by nanodrop. The cloned products were examined for an plasmid insert by PCR amplification with T7 forward (TAA TAC GAC TCA CTA TAG GG) and SP6 reverse primers, and the expected size was analysed by agarose $(2 \%)$ gel electrophoresis. Cloned product was sent for sequencing. The obtained sequence has been submitted to GenBank, and it is available from the GenBank sequence database under accession number JQ972060.

Most probable number (MPN) technique

The MPN for AOB was carried out specifically, which was described by Sarathchandra (1979). The medium used for 
MPN estimations for AOB contained $\left(\mathrm{NH}_{4}\right)_{2} \mathrm{SO}_{4}-0.5 \mathrm{~g}$; $\mathrm{KH}_{2} \mathrm{PO}_{4}-0.2 \mathrm{~g} ; \quad \mathrm{MgSO}_{4} \cdot 7 \mathrm{H}_{2} \mathrm{O}-0.2 \mathrm{~g} ; \quad \mathrm{CaCI}_{2} \cdot 2 \mathrm{H}_{2} \mathrm{O}-$ $0.02 \mathrm{~g}$; phenol red $-0.0075 \mathrm{~g}$; and trace elements, $10 \mathrm{ml}$ in a litre of distilled water. Trace elements' solution contained (/L) $\mathrm{NaMoO}_{4} \cdot 2 \mathrm{H}_{2} \mathrm{O}-10 \mathrm{mg} ; \mathrm{MnCl}_{2} \cdot 4 \mathrm{H}_{2} \mathrm{O}-20 \mathrm{mg}$; $\mathrm{COCl}_{2} \cdot 6 \mathrm{H}_{2} \mathrm{O}-0.2 \mathrm{mg} ; \quad \mathrm{CuSO}_{4} \cdot 5 \mathrm{H}_{2} \mathrm{O}-2 \mathrm{mg} ; \quad \mathrm{ZnSO}_{4}$. $7 \mathrm{H}_{2} \mathrm{O}-10 \mathrm{mg} ; \mathrm{FeSO}_{4} \cdot 7 \mathrm{H}_{2} \mathrm{O}-770 \mathrm{mg}$; and Na-EDTA$1.03 \mathrm{~g}$. The $\mathrm{pH}$ of the medium was adjusted to 8.2 with $0.1 \mathrm{~N} \mathrm{NaOH}$, and $5 \mathrm{ml}$ quantity of the medium was distributed into test tubes $(150 \mathrm{~mm} \times 15 \mathrm{~mm})$, which were then plugged and autoclaved at $121{ }^{\circ} \mathrm{C}$ for $10 \mathrm{~min}$. After sterilisation, $\mathrm{pH}$ dropped to 7.77-7.8. The biomass from aerobic reactors was taken for MPN estimations. Tenfold dilutions of $\mathrm{M}_{\mathrm{AOB}}$ reactor biomass samples were prepared in distilled water. Aliquots $(1 \mathrm{~mL})$ of suitable dilutions were inoculated into test tubes containing medium and incubated at $37^{\circ} \mathrm{C}$. The growth of ammonium-oxidising bacteria in the medium was estimated at the intervals of 1 or 2 weeks. The presence or absence of ammonium-oxidising bacteria was monitored visually by observing whether the colour of the test medium remained pink (no growth) or turned yellow (growth) because of the decrease in $\mathrm{pH}$ resulting from the bacterial oxidation of ammonium. MPN was calculated depending upon the positive and negative tubes (Thomas formula).

\section{Results and discussion}

\section{Seed characteristics}

The initial physicochemical characteristics of the seed used in the 100-mL reactors such as fresh MSW, mined MSW, leachate, and slurry are presented in the Table 4 . The fresh MSW and slurry showed higher moisture content of 47 and $44 \%$, respectively, when compared to the partially degraded waste with $29 \%$. The observations are in line with the values reported in the literature having higher moisture content for fresh MSW and lower moisture content for mined waste (Karthikeyan et al. 2007 and Sri Shalini et al. 2010). The volatile fraction was higher in fresh MSW (44\%) and mined MSW (21\%) than slurry $(17 \%)$. The characteristics of fresh MSW and mined MSW were similar to the results obtained in the study by Sri Shalini et al. (2010). Organic load was higher in fresh MSW $(10 \mathrm{~g} / \mathrm{kg})$ with higher biodegradable fraction than mined MSW. Ammoniacal nitrogen load in the seeds was higher in slurry $(2.18 \mathrm{~g} / \mathrm{kg})$ than fresh MSW $(0.24 \mathrm{~g} / \mathrm{kg})$, mined MSW $(0.12 \mathrm{~g} / \mathrm{kg})$, and leachate $(0.35 \mathrm{~g} / \mathrm{L})$. Nitrate nitrogen concentration was present in all the seeds but nitrite concentrations were low.

The second sampling of mined MSW was carried out for usage as seeds in 2.5-L reactors and its characteristics are presented in Table 4. It showed that the characteristics were similar to that of the first sampling of mined MSW with moisture content of $19.2 \%$ and volatile solids of $13.8 \%$. The total organic carbon content was $8.45 \mathrm{~g} / \mathrm{kg}$ with ammoniacal nitrogen content of $0.11 \mathrm{~g} / \mathrm{kg}$. From the Table 4, the results showed sufficient volatile fraction and adequate quantity of nitrogen was present in all the seeds; hence, no external addition of nitrogen was required for the start-up of the enrichment of the aerobic and anaerobic ammonium-oxidising bacteria in $100-\mathrm{mL}$ and $2.5-\mathrm{L}$ batch reactors.

Enrichment of aerobic ammonium-oxidising bacteria (AOB) in aerobic reactors

The nine reactors namely FA, FB, MA, MB, SA, SB, LA, $L B$, and $M_{A O B}$ were assessed for the growth of the aerobic ammonium-oxidising bacteria. The source of the seed for the enrichment of AOB was from municipal solid waste dumpsite, and the MSW loaded in the reactors was in the range of 13.4-36.4 $\mathrm{g}$ of TS (100-mL reactors) and $337 \mathrm{~g}$ of TS (2.5-L reactors) (Table 2). The nitrogen loads in the

Table 4 Initial characteristics of seed

\begin{tabular}{|c|c|c|c|c|c|c|}
\hline \multirow[t]{2}{*}{ Sl. no } & \multirow[t]{2}{*}{ Parameters } & \multicolumn{4}{|c|}{ Seed for $100-\mathrm{mL}$ reactors } & \multirow{2}{*}{$\begin{array}{l}\text { Seed for } 2.5-\mathrm{L} \text { reactors } \\
\text { Mined MSW }\end{array}$} \\
\hline & & Fresh MSW & Mined MSW & Slurry & Leachate & \\
\hline 1. & Moisture content $(\%)$ & 47 & 29 & 44 & & 19.2 \\
\hline 2. & Total solids $(\%)$ & 53 & 71 & 56 & $9,676 \mathrm{mg} / \mathrm{L}$ & 80.8 \\
\hline 3. & Volatile solids $(\%)$ & 44 & 21 & 17 & & 13.8 \\
\hline 4. & $\mathrm{pH}$ & 8.4 & 7.5 & 7.3 & 7.4 & 7.9 \\
\hline 5. & Conductivity $(\mu \mathrm{S} / \mathrm{cm})$ & 3,520 & 1,321 & 1,270 & 9,540 & 1,360 \\
\hline 6. & Water-soluble Ammonia-N (g/kg) & 0.24 & 0.12 & 2.18 & $0.35 \mathrm{~g} / \mathrm{L}$ & 0.11 \\
\hline 7. & Water-soluble Nitrate-N (g/kg) & 0.23 & 0.05 & 0.03 & $0.02 \mathrm{~g} / \mathrm{L}$ & 0.12 \\
\hline 8. & Water-soluble Nitrite-N (g/kg) & 0.0001 & 0.004 & BDL & 0.003 & 0.03 \\
\hline 9. & Water-soluble COD (g/kg) & 10 & 6 & 5 & $36 \mathrm{~g} / \mathrm{L}$ & 8.5 \\
\hline
\end{tabular}


FA

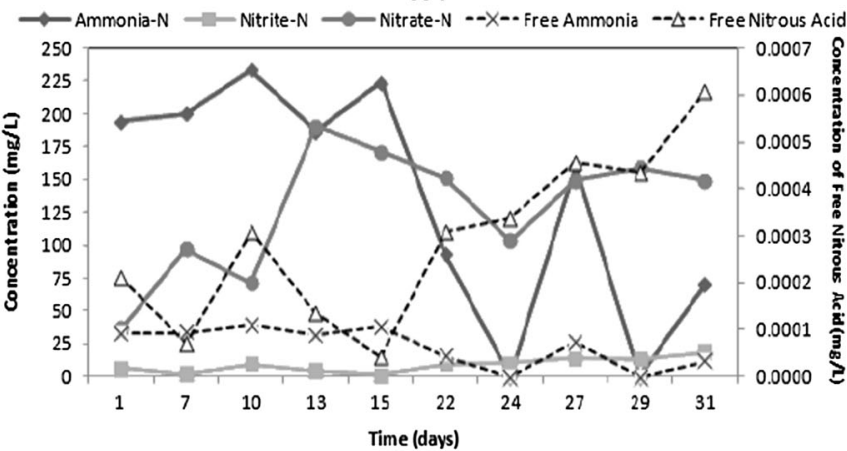

MA

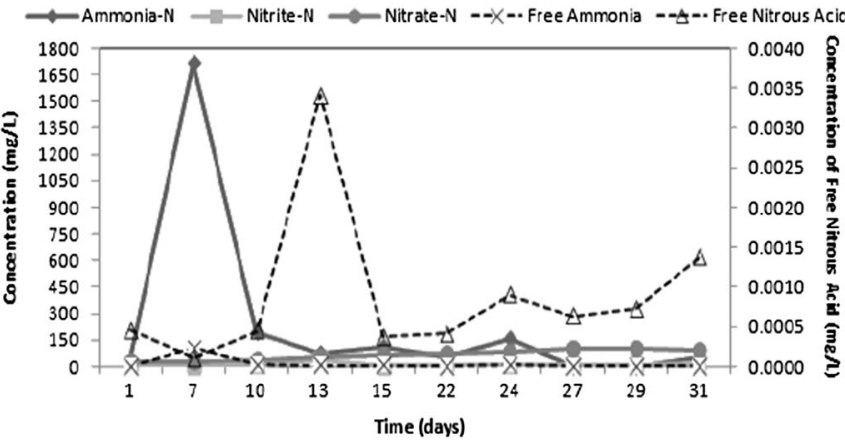

SA

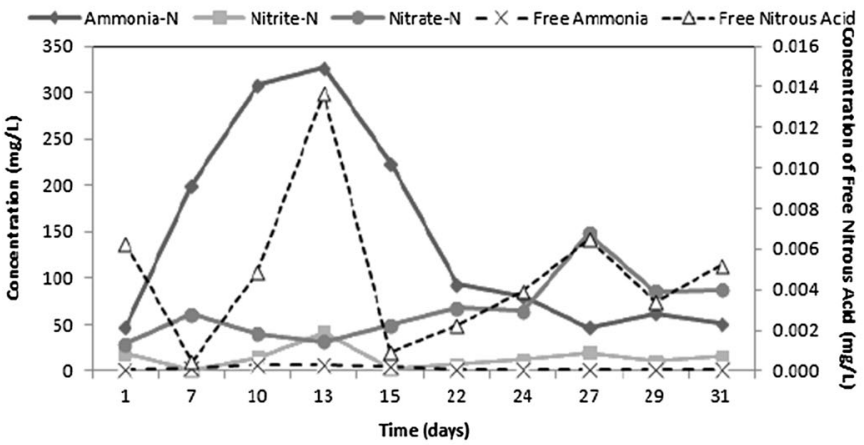

LA

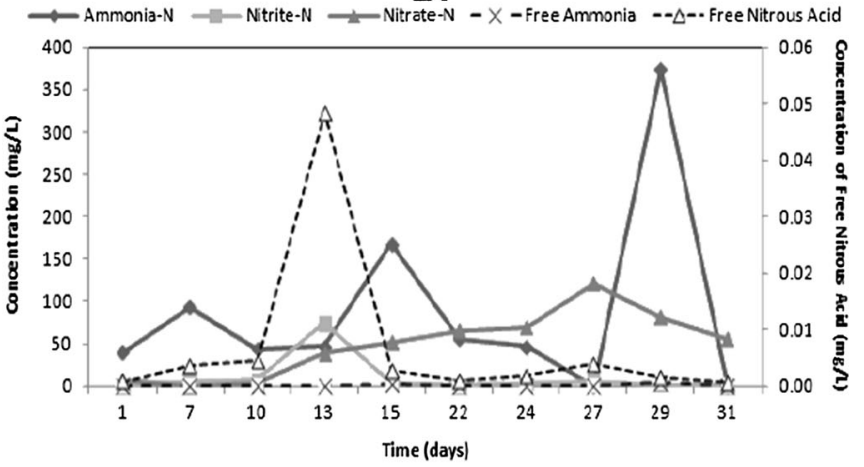

Fig. 2 Nitrogen transformation profiles and concentration of free ammonia and free nitrous acid during enrichment of AOBs in 100-mL reactors. Description Free ammonia and free nitrous acid are calculated based upon the variations in temperature and $\mathrm{pH}$, and the
FB

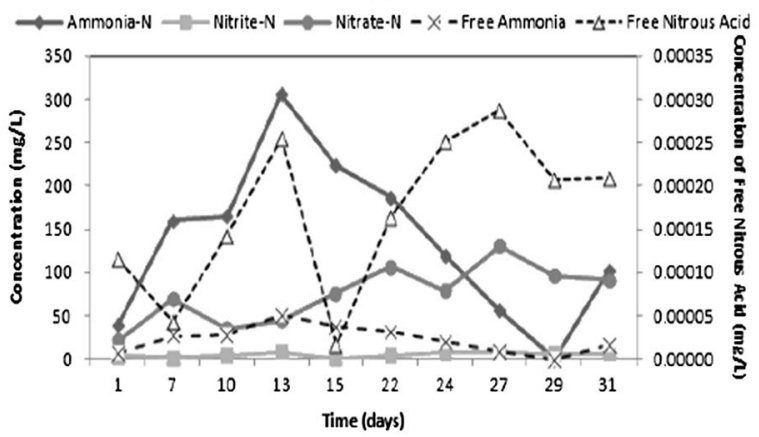

$M B$

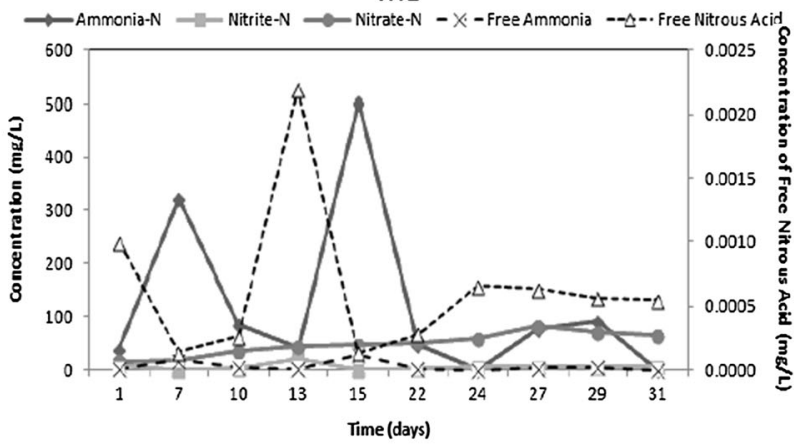

SB

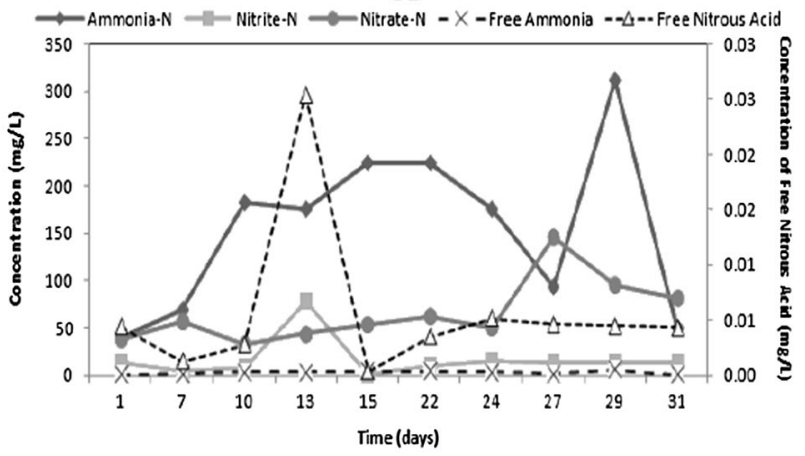

LB

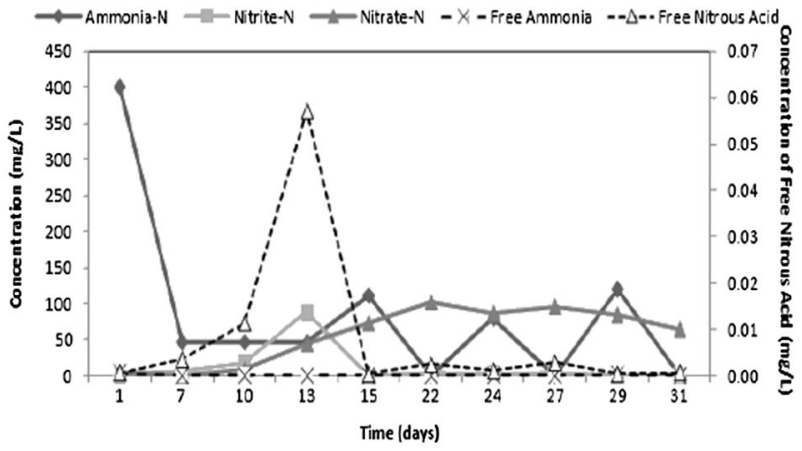

concentrations of ammoniacal nitrogen in the reactors and variations in Ammonia-N, Nitrite-N, and Nitrate-N during the AOB enrichment in $100-\mathrm{mL}$ reactor are depicted 
reactors were $0.1-2.2 \mathrm{~g} / \mathrm{kg}$. The aim of the study is to build up AOB for conducting the SHARON process, and this can be achieved by obstructing the growth of nitrite-oxidising bacteria (NOB) from the reactors. As NOBs are the main competitor for $\mathrm{AOB}$ in substrate utilisation; if they are inhibited, AOB can grow faster and nitrite accumulation takes place (Paredes et al. 2007).

The important operational parameters for AOBs to grow require optimum $\mathrm{pH}$, temperature, and $\mathrm{DO}$. When monitoring the start-up of the various aerobic reactors, the $\mathrm{pH}$ of the reactors was in the range of 7-8.3 [mined MSW-7.8 (MA and MB), fresh MSW-8.3 (FA and FB), slurry-7.3 (SA and $\mathrm{SB}$ ), leachate-7 (LA and $\mathrm{LB})$ and $\left.7-7.5\left(\mathrm{M}_{\mathrm{AOB}}\right)\right]$. This indicated the favourable condition for the AOBs to grow. For $\mathrm{AOB}, \mathrm{NH}_{3}$ is the actual substrate rather than $\mathrm{NH}_{4}$ and $\mathrm{HNO}_{2}$ is the inhibiting component. The $\mathrm{pH}$ assigns the distribution of $\mathrm{NH}_{4} / \mathrm{NH}_{3}$ and $\mathrm{NO}_{2} / \mathrm{HNO}_{2}$ equilibrium (Anthonisen et al. 1976; Paredes et al. 2007). During the operation of the reactors, the changes in the $\mathrm{pH}$ had an effect on the concentration of free ammonia and free nitrous acid, which is depicted in Figs. 2 and 3. Figures showed that more $\mathrm{NH}_{3}$ and less $\mathrm{HNO}_{2}$ were produced, which clearly promotes AOB but suppresses NOB (Hellinga et al. 1998; Zhang et al. 2008).

To accumulate nitrite on a long-term basis, using $\mathrm{pH}$ as a key parameter alone was not adequate, and hence, other operating parameters like DO and temperature were required (Sinha and Annachattre 2007). DO was in the range of $1.5-3.5 \mathrm{mg} / \mathrm{L}$, and average DO maintained in the reactors was above $1.0 \mathrm{mg} / \mathrm{L}$. Sufficient DO concentration was prevailing in the reactors, and hence, there existed a growth competition between the nitrifying bacteria (AOBs and NOBs). The temperature was almost around $30^{\circ} \mathrm{C}$ during the operational period. It has been shown that AOBs can grow faster than NOBs at temperatures greater than $15^{\circ} \mathrm{C}$, and around $25^{\circ} \mathrm{C}$, the AOBs can outcompete NOBs (Paredes et al. 2007). As higher temperatures prevailed in the reactors, AOBs were accumulated and NOBs were inhibited. The conductivity of the reactors showed an increasing trend as the ions are leached out from the waste during the study. From monitoring the operational parameters of the reactors $\mathrm{FA}, \mathrm{FB}, \mathrm{MA}, \mathrm{MB}, \mathrm{SA}, \mathrm{SB}, \mathrm{LA}, \mathrm{LB}$, and $\mathrm{M}_{\mathrm{AOB}}$, it showed that the optimum condition existed for AOBs to grow (Paredes et al. 2007; Zhang et al. 2008).

AOBs enrichment in 100-mL reactors

The enrichment of AOBs is initially started in the 100-mL reactors with four different set of seeds with two sets of variation in reactor loading as presented in Table 2 . The nitrogen transformations in the reactors during the enrichment of AOBs
Fig. 3 a Nitrogen transformation profiles and b concentration of free ammonia and free nitrous acid during enrichment of AOBs in 2.5-L reactors.

Description Ammonia-N, Nitrite- $\mathrm{N}$, and Nitrate-N variations during the $\mathrm{AOB}$ enrichment in $2.5-\mathrm{L}$ reactor are depicted (a)

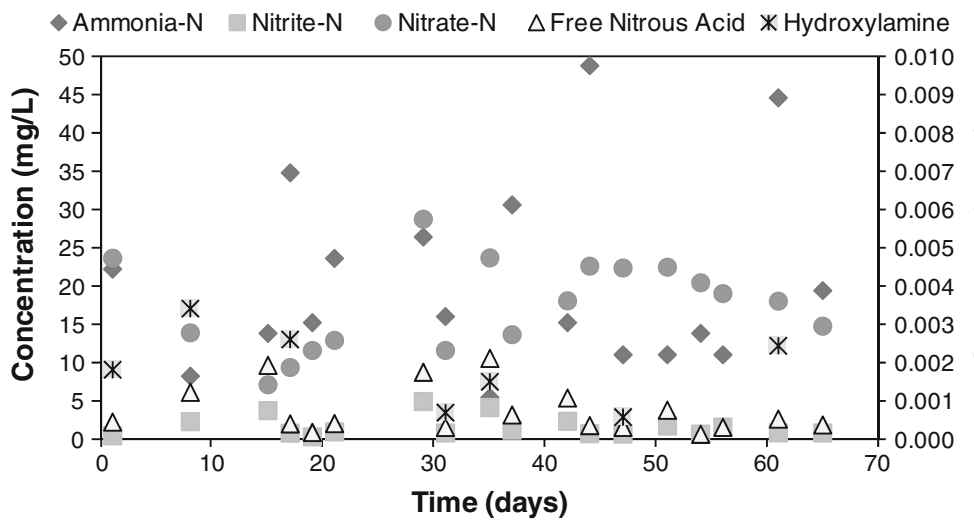

(b)

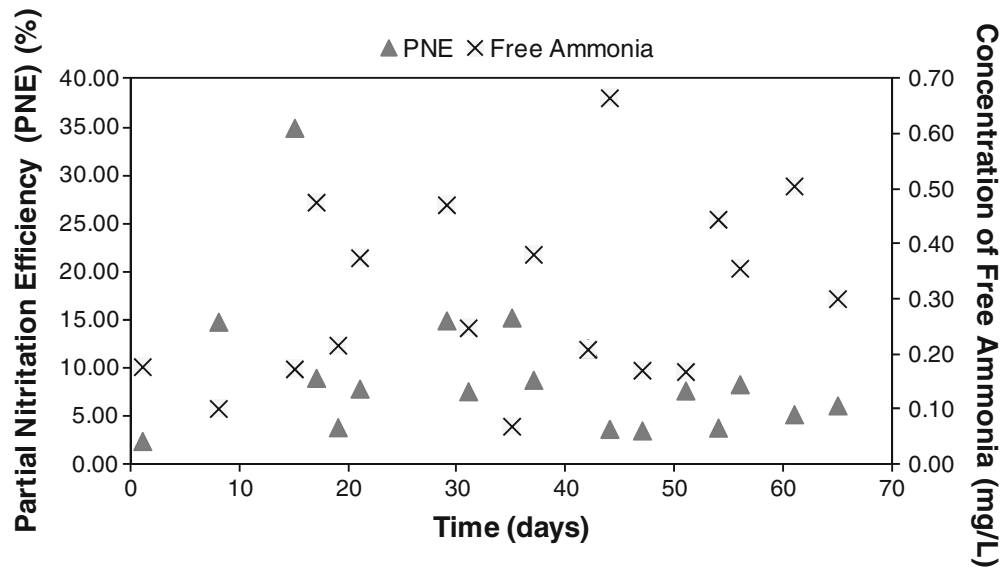


are depicted in the Fig. 2. The initial ammoniacal nitrogen concentrations in the reactors were LB-400 mg/L; FA$194 \mathrm{mg} / \mathrm{L} ; \mathrm{SA} — 47 \mathrm{mg} / \mathrm{L} ; \mathrm{FB}, \mathrm{MA}, \mathrm{SB}$, and MB-40 mg/L, respectively. On the first week (Day 7 ) of the reactor operation, the ammoniacal nitrogen concentration increased above the initial concentration in reactors loaded only with solid waste as shown in Fig. 2 (FA, FB, MA, MB, SA, and SB) due to leaching of ammoniacal nitrogen from the solid waste. Hence, the removal of ammoniacal nitrogen was calculated from the first week till the end of study period except for the reactors with LA and LB, which contained only leachate (no solid waste). Removal of ammoniacal nitrogen during the end of the study period was FA-65\%, FB-36 \%, MA-97\%, $\mathrm{MB}-100 \%, \mathrm{SA}-75 \%$, and $\mathrm{SB}-27 \%$.

The nitrite accumulation rate is an indication of the activity of AOBs, and as the rate increases, it shows that the activity of AOBs is more. The nitrite accumulation rate was calculated by partial nitritation efficiency (PNE) according to Liang and Liu (2007), which is an important parameter for the measurement of AOBs. The variations in nitrite and nitrate concentrations are depicted in the Fig. 2. Changes in nitrogen levels in the form of ammonia, nitrite, and nitrate varied depending upon the source of seed. The maximum nitrite accumulation rate with $100 \%$ PNE was reached in reactors loaded with leachate on day 7 . Other reactors reached the maximum PNE on day 13 with $14 \%-\mathrm{FB}$, $35 \%-\mathrm{MA}$ and MB, and $61 \%-\mathrm{SA}$ and SB. The nitrite-toammonium ratio was better in $\mathrm{LA}, \mathrm{LB}$, and $\mathrm{MB}$ when compared to other reactors.

The nitrite accumulation was inhibited by the NOBs, which is the actual competitor for AOBs. Both the AOBs and NOBs are inhibited with free ammonia and/or free nitrous acid (FNA) (Anthonisen et al. 1976; Ganigue et al. 2007). But, NOBs are more sensitive to free ammonia than AOBs. The concentration of free ammonia and FNA present in the reactors during the entire study period is depicted in the Fig. 2. From the figure, it shows that the free ammonia values in different reactors were above $0.1 \mathrm{mg} / \mathrm{L}$, which is an inhibitory level for NOBs. The reactors never reached the free ammonia levels above $150 \mathrm{mg} / \mathrm{L}$, which is said to be the inhibitory level for AOBs (Anthonisen et al. 1976). Hence, AOBs were not inhibited in any reactor, only NOBs were inhibited. Nitrite accumulation occurred in the reactor was confirmed by the PNE. Concerning free nitrous acid concentrations, the maximum value elevated in the reactors was $0.017 \mathrm{mg} / \mathrm{L}$, which is less than the inhibitory range of $0.2 \mathrm{mg} / \mathrm{L}$ for AOBs and NOBs as reported by Anthonisen et al. (1976). Hence, NOBs were mainly inhibited due to free ammonia not due to free nitrous acid concentrations in the reactors. The results are further supported by the study conducted by Ganigue et al. (2007) who reported similar trend in free ammonia and free nitrous acid concentrations in his work.
The concentration of organic carbon (as COD) initially available in the reactors was around FA-30,000, FB-22, 143, MA-6429, MB-10,000, SA-11,429, SB-10,625, LA-4167, and LB-5,833 mg/L, respectively, and showed the chance of some existence of heterotrophic biomass during the start-up of the study. But as the operation of the reactors was carried out without any organic carbon in the feed, the AOBs dominated to grow (Guven et al. 2009). Biomass concentrations in the reactors loaded with mined MSW had higher MLSS and MLVSS content (57,082 and $25,761 \mathrm{mg} / \mathrm{L})$ than slurry-fed reactor $(25,000$ and $9,762 \mathrm{mg} / \mathrm{L})$ and fresh waste $(20,572$ and $8,896 \mathrm{mg} / \mathrm{L})$. The MLSS and MLVSS concentrations showed that sufficient biomass was available in all the reactors. The confirmation of the AOBs was analysed through the presence of intermediates such as hydroxylamine and hydrazine. The occurrence of hydroxylamine and hydrazine compounds in all the reactors is presented in the Table 5. The results illustrated that ample concentrations of intermediates in the reactors established the enrichment of AOBs in all the aerobic reactors, which is supported by Peng and Zhu (2006). The replicability of the experiment was validated by Pearson's correlation analysis, which showed significantly strong correlation with $90-100 \%$ (at $95 \%$ confidence level) in different reactors.

The nitrogen transformation profiles, MLSS and MLVSS concentrations, and the presence of hydrazine and hydroxylamine concentrations confirmed the enrichment of AOBs in 100-mL reactors (Fig. 2). Although the reactors with four sets of seeds with two variations in loading (MA, $\mathrm{MB}, \mathrm{FA}, \mathrm{FB}, \mathrm{SA}, \mathrm{SB}, \mathrm{LA}$, and $\mathrm{LB}$ ) gave good results for AOBs enrichment, the reactor $\mathrm{MB}$ (i.e. reactor with mined waste with Feed/Seed: 80/20) was considered to be best for

Table 5 Hydrazine and hydroxylamine concentrations in aerobic and anaerobic reactors

\begin{tabular}{clll}
\hline Parameters & $\begin{array}{l}\text { Feed-to-seed } \\
\text { ratio }\end{array}$ & $\begin{array}{l}\text { Hydroxylamine } \\
(\mathrm{mg} / \mathrm{L})\end{array}$ & $\begin{array}{l}\text { Hydrazine } \\
(\mathrm{mg} / \mathrm{L})\end{array}$ \\
\hline Mined & $\mathrm{A}$ & 0.005 & 0.090 \\
MSW & $\mathrm{B}$ & 0.007 & 0.040 \\
& $\mathrm{C}$ & 0.003 & 0.005 \\
Fresh & $\mathrm{A}$ & 0.025 & 0.200 \\
MSW & $\mathrm{B}$ & 0.009 & 0.110 \\
& $\mathrm{C}$ & 0.008 & 0.102 \\
Slurry & $\mathrm{A}$ & 0.015 & 0.230 \\
& $\mathrm{~B}$ & 0.024 & 0.200 \\
& $\mathrm{C}$ & 0.003 & 0.083 \\
Leachate & $\mathrm{A}$ & 0.001 & 0.090 \\
& $\mathrm{~B}$ & 0.002 & 0.034 \\
& $\mathrm{C}$ & 0.001 & 0.016 \\
\hline
\end{tabular}


the long-term enrichment studies of AOBs from municipal solid waste. This was due to the difficulties in operating other reactors like FA, FB, SA, SB, LA, and LB with several issues like high evaporation rate and growth of biomass on the sides of the reactor wall dealt with flies disturbance changed the ambience of the reactors. On comparison with other reactors, $\mathrm{MB}$ was considered to be an optimum choice for the enrichment of AOBs (Fig. 2 and Table 5) in large-scale reactors attributable to higher removal rate of ammoniacal nitrogen $(100 \%)$, good nitrite accumulation rate and reaching 1:1 ratio of $\mathrm{NO}_{2} / \mathrm{NH}_{4}$, higher biomass accumulation (MLSS- $57,082 \mathrm{mg} / \mathrm{L}$ and MLVSS-25,761 mg/L), higher COD removal rate (>90\%), adequate concentrations of the occurrence of hydroxylamine $(0.007 \mathrm{mg} / \mathrm{L})$ and hydrazine $(0.040 \mathrm{mg} / \mathrm{L})$, lesser evaporation, and no growth of biomass on the sides of the reactor. This led to further investigations on the enrichment of AOBs in scale-up studies using mined municipal solid waste with Feed/Seed: 80/20 loading rate.

\section{AOBs enrichment in 2.5-L reactors}

The variations in the ammoniacal nitrogen, nitrite, and nitrate concentrations during the enrichment of AOBs in the 2.5-L reactors are depicted in the Fig. 3a. The removal of ammoniacal nitrogen was higher than $50 \%$ in the first week and reached the maximum percentage of removal on day 35 with $74 \%$, achieving to $\mathrm{NO}_{2}-\mathrm{N} / \mathrm{NH}_{4}-\mathrm{N}$ ratio of 1:1. The effluent of this reactor with 1:1 ratio of $\mathrm{NO}_{2}-\mathrm{N} / \mathrm{NH}_{4}-\mathrm{N}$ can be used as the influent for treating it by anammox process. Similar to the study conducted by Liang and Liu (2007), the increase in temperature $\left(27-34^{\circ} \mathrm{C}\right)$ contributed for higher removal of ammoniacal nitrogen. The nitrate level never exceeded $24 \mathrm{mg} / \mathrm{L}$. The variations in the nitrite and nitrate concentrations and the nitrite accumulation rate (PNE) are depicted in the Fig. 3a, b. About $35 \%$ PNE was reached in the reactors in 17 days.

The concentrations of FA and FNA present in the reactors during the entire study period are also depicted in the Fig. 3a, b. The concentrations of FA in the reactors during the study were above $0.1 \mathrm{mg} / \mathrm{L}$, which is an inhibitory value for NOBs according to Anthonisen et al. (1976). As the FA levels never reached greater than $1.0 \mathrm{mg} / \mathrm{L}$, AOBs were not inhibited by FA consequently nitrite accumulation occurred in the reactors (Fig. 3b). The FNA values were in the range of $0.0002-0.0022 \mathrm{mg} / \mathrm{L}$ in the reactors (Fig. 3a), which were not an inhibitory range for AOBs and NOBs (Anthonisen et al. 1976). The trend in FA and FNA in the reactors was similar to the $100-\mathrm{mL}$ reactors (Fig. 2). This illustrated that NOBs inhibition was due to the concentrations of FA rather than FNA levels in the reactors (Ganigue et al. 2007). The initial COD concentration in the reactor was around $370 \mathrm{mg} / \mathrm{L}$ and the level elevated to $1,428 \mathrm{mg} / \mathrm{L}$ in 15 days caused by the leaching of organic matter from the mined waste containing watersoluble organic matter of $8.45 \mathrm{~g} / \mathrm{kg}$. As the study progressed, the COD concentration decreased to $607 \mathrm{mg} / \mathrm{L}$ at the end. Even the heterotrophic biomass grown initially during the start-up of the study was caused by the concentration of organic carbon content present in the reactors occurred from the loaded seed (MSW), existed as the source. But as the study proceeded with the feed which was free of organic carbon, the AOBs grew predominantly in the study period as supported by Guven et al. (2009).

The availability of bicarbonates (alkalinity) is essential for AOBs (Hellinga et al. 1998; Ganigue et al. 2009). The conversion of ammoniacal nitrogen to nitrite nitrogen is an acidifying process that can be neutralised by bicarbonates (Zhang et al. 2008). Hence, bicarbonates were added as part of enrichment medium in the reactors to maintain the reaction. Subsequently, an increasing trend in the alkalinity concentration from 770 to $2,450 \mathrm{mg} / \mathrm{L}$ was observed. The results showed adequate amount of bicarbonates was available in the reactors for AOB organisms to grow. Initially, the MLSS concentration in the reactor was around $3.30 \mathrm{~g} / \mathrm{L}$ with MLVSS content of $1.22 \mathrm{~g} / \mathrm{L}$. As the condition was favourable for the AOBs to grow, the MLSS concentration increased to $4 \mathrm{~g} / \mathrm{L}$ in the first week of the study. The MLVSS concentration was also increased to $2.0 \mathrm{~g} / \mathrm{L}$ within 20 days. On day 30, the MLSS concentration elevated to a level of $40 \mathrm{~g} / \mathrm{L}$ with the MLVSS concentration of $16 \mathrm{~g} / \mathrm{L}$. The results illustrated the accumulation of AOB biomass in the reactors. The activity of AOBs was confirmed by the presence of hydroxylamine and hydrazine concentrations in the reactors (Fig. 3a) (Peng and Zhu 2006). The occurrence of hydroxylamine in the reactors is depicted in the Fig. 3a, authenticated the presence of AOBs in the reactors. The hydrazine accumulation was also commenced in the first week of the reactor operation $(0.05 \mathrm{mg} / \mathrm{L})$. The hydrazine presence further validated the AOBs population. The repetition of the experiment with similar conditions resulted in 85-95\% correlation within the duplicate reactors.

\section{Confirmation studies for AOB (MPN analysis)}

The confirmation of AOB bacterial population was investigated by conducting the MPN analysis specific for AOB (Sarathchandra 1979) in aerobic ammonium-oxidising bacterial enrichment culture from the $\mathrm{M}_{\mathrm{AOB}}$ reactor. The visual identification of yellow colour formation in test tubes containing $\mathrm{M}_{\mathrm{AOB}}$ reactor samples observed after 2-week period of incubation at $37{ }^{\circ} \mathrm{C}$ demonstrated the growth of AOB. Actual values of MPN obtained for the reactor sample were $2.85 \times 10^{6} \mathrm{MPN} / 100 \mathrm{~mL}$. The result implied that an incubation period of 2 weeks at $37{ }^{\circ} \mathrm{C}$ was 
Fig. 4 Nitrogen transformation profiles and concentration of free ammonia and free nitrous acid during enrichment of AnAOBs in 100-mL reactors. Description Free ammonia and free nitrous acid are calculated based upon the variations in temperature and $\mathrm{pH}$, and the concentrations of ammoniacal nitrogen in the reactors and variations in Ammonia-N, Nitrite- $\mathrm{N}$, and Nitrate- $\mathrm{N}$ during the AnAOB enrichment in $100-\mathrm{mL}$ reactor are depicted
FC

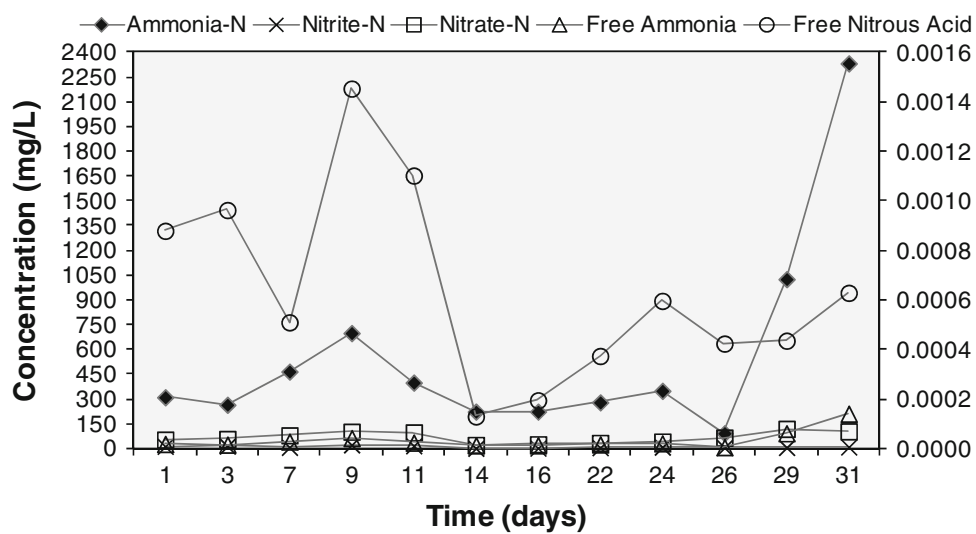

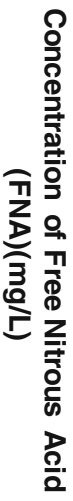

MC

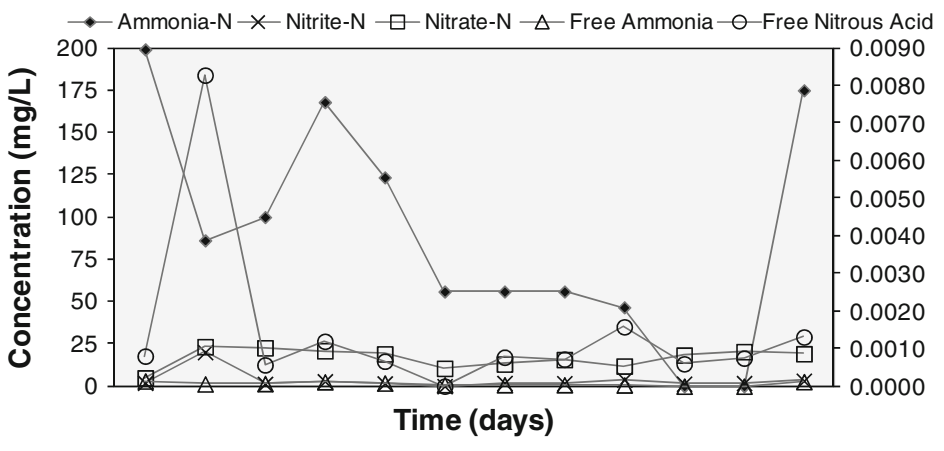

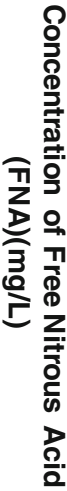

SC

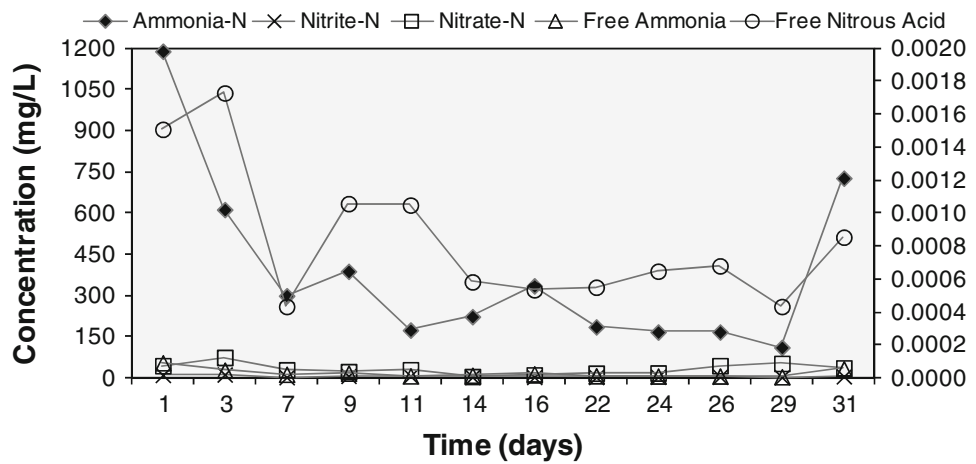

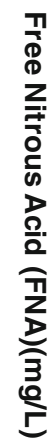

LC

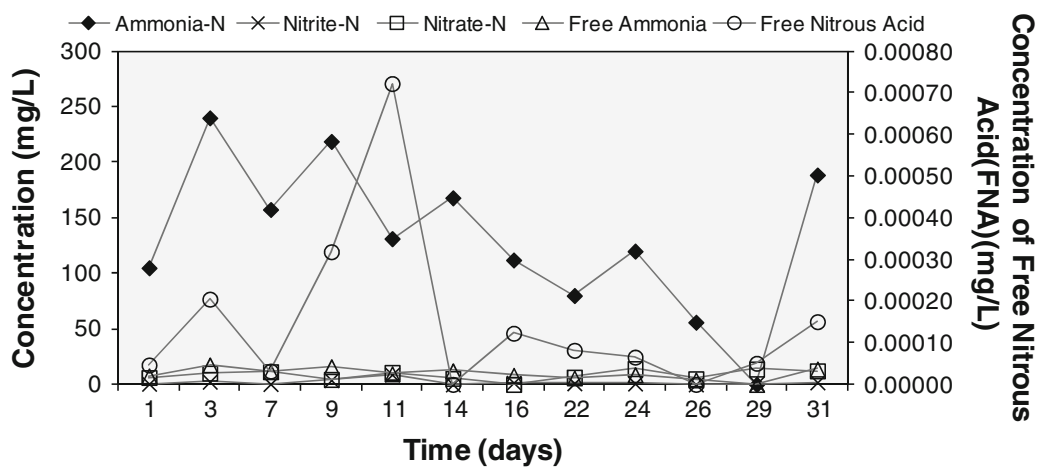


sufficient for the AOB bacteria to oxidise ammonium in ample quantity and subsequently decreased the $\mathrm{pH}$ (6.3-6.4) (Sarathchandra 1979). From the MPN results per $100 \mathrm{~mL}$, it illustrated that adequate quantity of population of AOB existed in the reactor. The nitrogen concentration profiles, biomass accumulation, occurrence of hydrazine and hydroxylamine concentrations along with the MPN results for $\mathrm{M}_{\mathrm{AOB}}$ reactor confirmed the enrichment of $\mathrm{AOB}$ from the mined MSW (Fig. 3).

Enrichment of anaerobic ammonium-oxidising bacteria (AnAOB)

The five reactors namely $\mathrm{FC}, \mathrm{MC}, \mathrm{SC}, \mathrm{LC}$, and $\mathrm{M}_{\mathrm{ANAOB}}$ were assessed for the growth of the anaerobic ammoniumoxidising bacteria, i.e. anammox bacteria in $100-\mathrm{mL}$ and 2.5-L reactors. The reactor loading details for the enrichment of AnAOB using different seeds is presented in Table 2. The MSW and nitrogen loads in the reactors were $11.9-25.7 \mathrm{~g}$ of TS (100 $\mathrm{mL}$ reactors), $473 \mathrm{~g}$ of TS $(2.5 \mathrm{~L}$ reactors), and $0.1-2.2 \mathrm{~g} / \mathrm{kg}$, respectively (Table 2). The anammox bacterial enrichment was observed in terms of operational parameters ( $\mathrm{pH}$, Temperature), nitrogen transformations, biomass development, and the presence of trace amounts of intermediates (van Dongen et al. 2001). The confirmation of anammox bacteria was carried out by SEM analysis and using molecular techniques (Arrojo et al. 2006; Ni et al. 2010).

The $\mathrm{pH}$ of the AnAOB reactors observed was as follows: $\mathrm{FC}-8.0, \mathrm{MC}-7.2, \mathrm{SC}-7.7, \mathrm{LC}-7.9$, and $\mathrm{M}_{\mathrm{AN}-}$ Аов-7.2-7.6 (Guven et al. 2004). The temperature of all the reactors was around $30-32{ }^{\circ} \mathrm{C}$ (Zhang and Zhou 2006). $\mathrm{pH}$ and temperature results demonstrated that the reactors were under optimum conditions for the anammox bacterial growth in the reactors $\mathrm{FC}, \mathrm{MC}, \mathrm{SC}, \mathrm{LC}$, and $\mathrm{M}_{\mathrm{ANAOB}}$ (Dapena-Mora et al. 2004; Guven et al. 2004). The anammox activity was initially analysed in four set of seeds in 100-mL reactors. Based upon the enrichment of anammox in 100-mL reactors, scale-up enrichment studies were carried out in $2.5-\mathrm{L}$ reactors with mined waste as seed.

Anammox enrichment in $100-\mathrm{mL}$ reactors

The characteristics of the seed used for the enrichment of anammox bacteria are presented in the Table 4, and the reactors namely $\mathrm{FC}, \mathrm{MC}, \mathrm{SC}$, and $\mathrm{LC}$ were loaded with Feed/Seed ratio of 60/40 (Table 2). The nitrogen concentration profiles in the anaerobic reactors during the enrichment of AnAOB are depicted in the Fig. 4. The initial ammoniacal nitrogen concentrations in the reactors are $\mathrm{FC}-311 \mathrm{mg} / \mathrm{L}, \mathrm{MC}-199 \mathrm{mg} / \mathrm{L}, \mathrm{SC}-1,190 \mathrm{mg} / \mathrm{L}$, and $\mathrm{LC}-105 \mathrm{mg} / \mathrm{L}$. The ammoniacal nitrogen removal efficiency achieved $70 \%-\mathrm{FC}, 100 \%-\mathrm{MC}, 86 \%-\mathrm{SC}$, and $47 \%$ - LC in 26 days.

Denitrifying bacterial activity was taking place initially due to the presence of nitrate and utilisation of COD as source of electron donors. The changes in nitrogen concentrations can only be due to microbial activity as there was no nitrogen addition except for the fresh medium added once in 2 days (Wang et al. 2009). The nitrite source for utilisation as electron acceptor for the development of anammox biomass was available in the reactors. During the start-up of the reactors, the nitrite was present in low concentration in seeds, but further nitrite concentration was produced due to the activity of nitrifiers evolved with the initial dissolved oxygen present in the reactors. The anammox biomass was developed by using this nitrite as electron acceptor (Reginatto et al. 2005). The concentration of nitrate in the reactors demonstrated that nitrate was probably evolved from nitrite to generate reducing equivalents for carbon dioxide fixation and it showed the growth of biomass (Van de Graaf et al. 1996). The initial COD concentration of the reactors $\mathrm{MC}, \mathrm{FC}, \mathrm{SC}$, and $\mathrm{LC}$ is 1,500 , $12,797,5,750$, and $500 \mathrm{mg} / \mathrm{L}$, respectively. The COD values in the reactors were due to the organic carbon present in the substrates, and no organic carbon source was given in the feed. The COD removal rates are higher in $\mathrm{MC}$ (48.4\%) and FC (45.7\%) than SC and LC. Removal of COD showed some heterotrophic biomass population could be existed in the reactors. The increase of organic carbon in LC from 250 to $531 \mathrm{mg} / \mathrm{L}$ during the end of the study must be produced due to lysis of any biomass (Liao et al. 2007).

The concentration of free ammonia in all the reactors (Fig. 4) was above $0.1 \mathrm{mg} / \mathrm{L}$ except for the LC on day 29, which is an inhibitory level for NOBs in the reactors (Anthonisen et al. 1976). At the end of the study, the FC elevated to the highest concentration of free ammonia to $212 \mathrm{mg} / \mathrm{L}$. It was shown that high concentration of free ammonia was found to inhibit anammox reaction (Molinuevo et al. 2009). The free nitrous acid concentrations in the reactors (Fig. 4) were in the range of $0.0001-0.0015 \mathrm{mg} / \mathrm{L}-\mathrm{FC}, 0$ $0.0083 \mathrm{mg} / \mathrm{L}-\mathrm{MC}, \quad 0.0004-0.0017 \mathrm{mg} / \mathrm{L}-\mathrm{SC}$, and 0-0.00072 mg/L-LC. Biomass as MLSS concentrations in different reactors is $10,415 \mathrm{mg} / \mathrm{L}-\mathrm{FC}, 8,572 \mathrm{mg} / \mathrm{L}-\mathrm{MC}$, $17,000 \mathrm{mg} / \mathrm{L}-\mathrm{SC}$, and $21,790 \mathrm{mg} / \mathrm{L}-\mathrm{LC}$. The existence of AnAOB organisms and biomass accumulation were proved by the MLSS concentrations.

The occurrence of hydrazine and hydroxylamine in all the reactors namely $\mathrm{FC}, \mathrm{MC}, \mathrm{SC}$, and LC was obtained and its concentrations are presented in the Table 5. The presence of trace amounts of the intermediates was added as the proof of enrichment of AnAOB in all the reactors (Shivaraman and Shivaraman 2003). Higher concentrations of hydrazine and hydroxylamine are accumulated in the 
reactors loaded with MSW (Table 5). The colour of the biomass was also changed from dark black colour to brownish colour in a period of 50 days due to the development of anammox bacteria having an ample content of cytochrome $\mathrm{c}$ in it (Liao et al. 2007). The reactors are validated by the duplicate reactors, which gave 85-99\% correlation (at $95 \%$ confidence level).

Confirmation studies for anammox bacteria in 100-mL reactors (SEM analysis)

The confirmation studies for anammox bacteria in 100-mL reactors were carried out by SEM analysis. The morphology and inner structure of the enriched AnAOB biomass in the $100-\mathrm{mL}$ reactors were observed in more detail with the scanning electron microscopy [Photographs are as shown in Online Resource 1 (SEM_FC, MC, SC, and LC)]. The SEM images of the enriched AnAOB biomass in the reactors showed were mostly spherical and elliptical bacteria with single cells and clusters having a rough surface which were interspersed (Arrojo et al. 2006; Ni et al. 2010). There were also presence of few other organisms by the identification of different other structures like filamentous, tubular and rod-shaped bacteria, indicating the coexistence of anammox bacteria with other microbial populations like AOBs, NOBs, and denitrifiers in FC, MC, SC, and LC reactors (Wang et al. 2009).

Monitoring the nitrogen transformations, biomass development and accumulation of hydrazine and hydroxylamine concentrations along with the SEM analysis revealed the AnAOB activity and authenticated the enrichment of anammox bacteria (Fig. 4 and Online Resource 1). The results demonstrated the anaerobic reactors with fresh MSW, mined MSW, slurry, and leachate as good seed for the enrichment of AnAOBs. But, the reactor with mined MSW (MC) was better than the other reactors for scale-up studies of the enrichment of anammox bacteria from MSW due to the reasons like comparison of ammoniacal nitrogen removal with other reactors (FC, SC, and $\mathrm{LC}$ ); MC gave $100 \%$ removal in 26 days, higher COD removal rate $(48.4 \%)$ than other reactors; accumulation of the hydroxylamine intermediates $(0.003 \mathrm{mg} / \mathrm{L})$ was similar to SC but higher than the LC $(0.001 \mathrm{mg} / \mathrm{L})$; free ammonia concentration never reached higher than $3.1 \mathrm{mg} / \mathrm{L}$, whereas the FC elevated to $212 \mathrm{mg} /$ $\mathrm{L}$ affected the anammox reaction. So, with these advantages of MC over other reactors, the mined MSW was used as seed for the enrichment of anammox bacteria in $2.5-\mathrm{L}$ reactors.

\section{Anammox enrichment in $2.5-\mathrm{L}$ reactors}

The variations in ammoniacal nitrogen, nitrite and nitrate concentrations during the enrichment of AnAOBs in the 2.5-L reactors are depicted in the Fig. 5. The ammoniacal nitrogen elevated to a level of $157 \mathrm{mg} / \mathrm{L}$ on day 19. About $56 \%$ of ammoniacal nitrogen removal took place in 29 days and the removal efficiency reached to $89 \%$ in 51 days. The concentration of nitrite was also simultaneously reduced to a level of $0.3 \mathrm{mg} / \mathrm{L}$ in 65 days due to consumption by the anammox bacteria as electron acceptor. The concentrations of nitrate prevailed in the reactor illustrated anammox activity was taking place (Fig. 5). From the figure, it illustrated that even after the adequate removal of ammoniacal nitrogen concentrations, there existed little amount of nitrite and nitrate concentrations, which demonstrated that some AOBs and NOBs might be existed along with the anammox bacteria. But, as the free ammonia concentration in the reactors was above $0.1 \mathrm{mg} / \mathrm{L}$ throughout the study period, the NOBs were mostly inhibited (Anthonisen et al. 1976). The free nitrous acid was in the range of $0-0.0022 \mathrm{mg} / \mathrm{L}$ (Fig. 5).

The range of conductivity and salinity was $4.3-5.2 \mathrm{mS} /$ $\mathrm{cm}$ and 2.7-3.1 psu, respectively. The conductivity and salinity has a similar increasing and decreasing trend, showed the leachability of ions from the waste. Alkalinity

Fig. 5 Nitrogen transformation profiles and concentration of hydroxylamine, free ammonia, and free nitrous acid during enrichment of AnAOBs in 2.5-L reactors.

Description Ammonia-N, Nitrite-N, and Nitrate-N variations during the $\mathrm{AnAOB}$ enrichment in $2.5-\mathrm{L}$ reactor is depicted

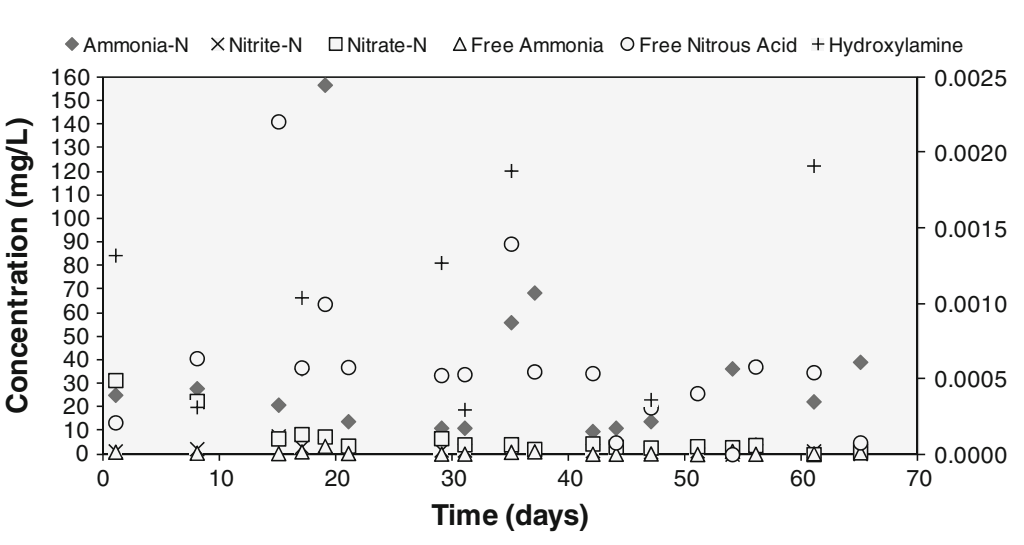


can be used as the indicated parameter for the anammox activity in the reactor (Zhang and Zhou 2006). The reactor had carbonates and bicarbonates, which were exhibited from the phenolphthalein and total alkalinity concentrations $(43-755 \mathrm{mg} / \mathrm{L}$ and $95-1,146 \mathrm{mg} / \mathrm{L}$, respectively). The nitrogen removal by anammox process was increased due to sufficient inorganic carbon source in the form of bicarbonates prevailed in the reactor (Yang et al. 2010). The COD concentration initially in the reactor was around $445 \mathrm{mg} / \mathrm{L}$, and it was elevated to $5,531 \mathrm{mg} / \mathrm{L}$ due to the leaching of organic matter from the mined waste containing water-soluble organic matter of $8.45 \mathrm{~g} / \mathrm{kg}$. At the end of the study period, the COD concentration reduced to $252 \mathrm{mg} / \mathrm{L}$. The results demonstrated that some heterotrophic biomass was existed in the reactor (similar to $100-\mathrm{mL}$ reactors), but as the feed used in the study was free of organic carbon, anammox process can only survive in the reactor. It was also illustrated from the biomass population, which elevated the MLSS concentration $(28,000 \mathrm{mg} / \mathrm{L})$ and MLVSS content (10,200 mg/L).

The occurrence of trace concentrations of hydrazine $(0.04 \mathrm{mg} / \mathrm{L})$ and hydroxylamine $(0.0003-0.002 \mathrm{mg} / \mathrm{L})$ in the reactor proved the enrichment of AnAOB (Fig. 5) (Shivaraman and Shivaraman 2003). The colour of the biomass was also changed from dark black colour to brownish colour in a period of 65 days due to the development of anammox bacteria (Liao et al. 2007). The replicability of the experiment was validated by correlation analysis resulting in $90-98 \%$ correlation in the reactors.

Confirmation studies for anammox bacteria in 2.5-L reactors (DNA extraction, PCR amplification, cloning, and sequencing of $16 \mathrm{~S}$ rRNA)

The anammox bacterial enrichment culture from the $\mathrm{M}_{\mathrm{AnAOB}}$ reactor was examined for the anammox bacterial population by targeting the anammox $16 \mathrm{~S}$ rRNA gene for the identification of $\mathrm{Ca}$. B. anammoxidans. Detection of anammox species was done by as explained in the methodology, and DNA was extracted from the biomass of the enrichment culture. Anammox 16S rRNA gene sequence was amplified using PCR with Brod541F and Amx820R primers and cloned. The clones were randomly selected for sequencing. The full-length anammox 16S rRNA sequences were obtained. The sequences were blast, and $C a$. B . anammoxidans species were identified. The sequence uploaded in the Genbank under the accession number JQ972060 and named as Candidatus Brocadia sp. enrichment culture clone AnAOBSSSKJ 16S ribosomal RNA gene, partial sequence. The anammox bacteria present in the reactor was C. Brocadia sp., Planctomycetes, Plantomycetia, and Candidatus brocadiales.
The variations in the nitrogen concentration profiles, biomass development (MLSS-28,000 mg/L and MLVSS - 10,200 mg/L), accumulation of hydrazine $(0.04 \mathrm{mg} / \mathrm{L})$ and hydroxylamine concentrations $(0.002 \mathrm{mg} /$ L) along with the identification of $\mathrm{Ca}$. B. anammoxidans using the molecular analysis of the reactor sample authenticated the enrichment of anammox bacteria from the mined MSW in the $2.5-\mathrm{L}$ reactors.

\section{Conclusion}

The study revealed the feasibility for using MSW and leachate as seed for enriching the aerobic and anaerobic ammonium-oxidising bacteria, which were not studied so far and it is an innovative research. The enrichment of $\mathrm{AOB}$ and $\mathrm{AnAOB}$ in batch reactors was confirmed based upon the variations in the ammoniacal nitrogen, nitrite and nitrate nitrogen, alkalinity, FA and FNA concentrations and biomass accumulation; it was also validated by the presence of intermediates such as hydrazine and hydroxylamine concentrations in the reactors. On comparison with different types of seeds used in the reactors, mined MSW with $80 / 20$ in aerobic loading and $60 / 40$ in anaerobic loading conditions illustrated the long-term feasibility for enriching the $\mathrm{AOB}$ and $\mathrm{AnAOB}$ in large-scale reactors. The results were authenticated by MPN analysis for AOB population and SEM and molecular analysis for AnAOB population.

Acknowledgments The support of the All India Council for Technical Education to carry out this study in the form of National Doctoral Fellowship to the corresponding author is gratefully acknowledged. The author wishes to thank Dr. Ammaiyappan Selvam and Dr. Su Yun Xu, Hong Kong Baptist University for their help in the molecular analysis of the bacteria.

\section{References}

Ahn YH (2006) Sustainable nitrogen elimination biotechnologies: a review. Process Biochem 41:1709-1721

Amano T, Yoshinga I, Okada K, Yamagishi T, Ueda S, Obuchi A, Sako Y, Suwa Y (2007) Detection of anammox activity and diversity of anammox bacteria related $16 \mathrm{~S}$ rRNa genes in coastal marine sediment in Japan. Microbes Environ 22:232-242

Anthonisen AC, Loehr RC, Prakasam TBS, Srinath EG (1976) Inhibition of nitrification by ammonia and nitrous acid. J WPCF $46: 835-852$

APHA (1998) Standard methods for the examination of water and wastewater, 20th edn. United Book Press, USA

Arrojo B, Mosquera-Corral A, Campos JL, M'endez R (2006) Effects of mechanical stress on anammox granules in a sequencing batch reactor (SBR). J Biotechnol 123:453-463

Behera PK (2006) Solid and solid waste analysis-a laboratory manual, 1st edn. Dominant Publishers, New Delhi, pp 47-50 
Berge ND, Reinhart DR, Townsend TG (2005) The fate of nitrogen in bioreactor landfills. Crit Rev Environ Sci Technol 35:365-399

Chamchoi N, Nitisoravut S (2007) Anammox enrichment from different conventional sludges. Chemosphere 66:2225-2232

Dapena-Mora A, Campos JL, Mosquerra-Corral A, Jetten MSM, Mendez R (2004) Stability of the ANAMMOX process in a gas-lift reactor and a SBR. J Biotechnol 110:159-170

Egli K, Langer C, Siegrist H-R, Zehnder AJB, Wagner M, van der Meer JR (2003) Community analysis of Ammonia and nitrite oxidisers during start-up of nitritation reactors. Appl Environ Microbiol 69:3213-3222

Frear DS, Burrell RC (1955) Spectrophotometric method for determining hydroxylamine reductase activity in higher plants. Anal Chem 27:1664-1665

Fux C, Siegrist H (2004) Nitrogen removal from sludge digester liquids by nitrification/denitrification or partial nitritation/anammox: environmental and economic considerations. Water Sci Technol 50:19-26

Fux C, Boehler M, Huber P, Brunner I, Siegrist H (2002) Biological treatment of ammonium-rich wastewater by partial nitritation and subsequent anaerobic ammonium oxidation (anammox) in a pilot plant. J Biotechnol 99:295-306

Ganigue R, Lopez H, Balaguer MD, Colprim J (2007) Partial ammonium oxidation to nitrite of high ammonium content urban landfill leachates. Water Resour 41:3317-3326

Ganigue R, Gabarro J, Sanchez-Melsio A, Ruscalleda M, Lopez H, Vila X, Colprim J, Balaguer MD (2009) Long-term operation of a partial pilot plant treating leachate with extreme high ammonium concentration prior to an anammox process. Bioresour Technol 100:5624-5632

Guven D, van de Pas-Schoonen K, Schmidt MC, Strous M, Jetten MSM, Sozen S, Orhon D, Schmidt I (2004) Implementation of the anammox process for improved nitrogen removal. J Environ Sci Health Part A Toxic/Hazar Subs Environ Eng A39:1729-1738

Guven D, Kutlu O, Insel G, Sozen S (2009) Model-based process analysis of partial nitrification efficiency under dynamic nitrogen loading. Bioprocess Biosyst Eng 32:655-661

Hellinga C, Schellen AAJC, Mulder JW, Van Lossdrecht MCM, Heijnen JJ (1998) The Sharon Process: an innovative method for nitrogen removal from ammonium-rich wastewater. Water Sci Technol 34:135-142

Jetten MSK, Schmid M, Schmidt I, Wubben M, Dongen UV, Abma W et al (2002) Improved nitrogen removal by application of new nitrogen-cycle bacteria. Rev Environ Sci Biotechnol 1:51-53

Jin RC, Hu BL, Zheng P, Qaisar M, Hu AH, Islam E (2008) Quantitative comparison of stability of ANAMMOX process in different reactor configurations. Bioresour Technol 99:1603-1609

Karthikeyan OP, Swati M, Nagendran R, Joseph K (2007) Performance of bioreactor landfill with waste mined from a dumpsite. Environ Monit Assess 135:141-151

Liang Z, Liu JX (2007) Control factors of partial nitritation for landfill leachate treatment. J Environ Sci (China) 19:523-529

Liao D, Yang Q, Zhao Z, Zeng G (2007) Enrichment and granulation of Anammox biomass started up with methanogenic granular sludge. World J Microbiol Biotechnol 23:1015-1020

Molinuevo B, Garcia CM, Karakashev D, Angelidaki I (2009) Anammox for ammonia removal from pig manure effluents: effect of organic matter content on process performance. Bioresour Technol 100:2171-2175

Ni S-Q, Lee P-H, Fessehaie A, Gao B-Y, Sung S (2010) Enrichment and biofilm formation of Anammox bacteria in a non-woven membrane reactor. Bioresour Technol 101:1792-1799

Paredes D, Kuschk P, Mbwette TSA, Stange F, Muller RA, Koser H (2007) New aspects of microbial nitrogen transformations in the context of waste water treatment-a review. Eng Life Sci 7:13-25

Peng B, Zhu G (2006) Biological nitrogen removal with nitrification and denitrification via nitrite pathway. Appl Microbiol Biotechnol 73:15-26

Penton CR, Devol AH, Tiedje JM (2006) Molecular evidence for the broad distribution of anaerobic ammonium-oxidizing bacteria in freshwater and marine sediments. Appl Environ Microbiol 72:6829-6832

Reginatto V, Teixera RM, Pereira F, Schmidell W, Furigo A, Menes $R$ et al (2005) Anaerobic ammonium oxidation in Bioreactor treating slaughterhouse wastewater. Braz J Chem Eng 22:593-600

Sarathchandra SU (1979) A simplified method for estimating ammonium oxidising bacteria. Plant Soil 52:305-309

Shivaraman N, Shivaraman G (2003) ANAMMOX - a novel microbial process for ammonium removal. Curr Sci 84:1507-1508

Sinha B, Annachhatre AP (2007) Assessment of partial nitrification reactor performance through microbial population shift using quinone profile, FISH and SEM. Bioresour Technol 98:3602-3610

Sri Shalini S, Karthikeyan OP, Joseph K (2010) Biological stability of municipal solid waste from simulated landfills under tropical environment. Bioresour Technol 101:845-852

Strous S, Heijnen JJ, Kuenen JG, Jetten MSM (1998) The sequencing batch reactor as a powerful tool for the study of slowly growing anaerobic ammonium-oxidising microorganisms. Appl Microbiol Biotechnol 50:589-596

Van de Graaf AA, Bruijn PD, Robertson LA, Jetten MSM, Kuenen JG (1996) Autotrophic growth of anaerobic ammonium oxidizing microorganisms in a fluidized bed reactor. Microbiology 142:2187-2196

van Dongen U, Jetten MSM, van Loosdrecht MCM (2001) The Sharon-Anammox process for treatment of ammonium rich wastewater. Water Sci Technol 44:153-160

Wang T, Zhang H, Yang F, Liu S, Fu Z, Chen H (2009) Start up of the ANAMMOX process from the conventional activated sludge in a membrane bioreactor. Bioresour Technol 100:2501-2506

Watt GW, Chrisp JD (1952) A spectrophotometric method for the determination of hydrazine. Anal Chem 24:2006-2008

Yang J, Zhang L, Fukuzaki Y, Hira D, Furukawa K (2010) High-rate nitrogen removal by the Anammox process with a sufficient inorganic carbon source. Bioresour Technol 101:9471-9478

Zhang H, Zhou S (2006) Treating leachate mixture with anaerobic ammonium oxidation technology. J Cent South Univ Technol $13: 663-667$

Zhang L, Zheng P, Tang C, Jin R (2008) Anaerobic ammonium oxidation for treatment of ammonium-rich wastewaters. J Zhejiang Univ Sci B 9:416-426 